\title{
BETWEEN STARS AND STRIPES: REGIONS FOR AMERICAN HEALTHCARE REFORM
}

By Brian Coyle

"Media Highlights" are
provided at the end of
this paper, starting p. 54.

INTRODUCTION

Major health care reform, such as a government run "public option" insurance program, an expansion of Medicare to include the 50 to 65 age group, or "Medicare for All," will reach hundreds of millions of people. Any of these programs need hundreds of thousands to millions of new employees. Rolling out such a program will be a massive challenge. It certainly will require an extended length of time - not a few years, but a decade or longer. Given the political controversies over federal programs, this requires sustaining a difficult, long-term commitment.

Extensive reforms will face dynamics like the Affordable Care Act did. Legislation will be influenced by medical industries. States where a significant number of beneficiaries are people of color will be centers of growing opposition. Channeled through the courts, the Supreme Court's conservative majority may quash important components. Progressive commitment will wane, as it did as when the ACA was rewritten and adjudicated. Immediate cost reductions and better care will lag predictions. Program flaws will be emphasized, as were difficulties in the roll-out of the ACA. Facing reality, centrists will decline to commit to the program, as they declined to support the ACA.

At the same time, the public are afraid to lose what they have. Since the ACA's implementation, fewer people face bankruptcy and barriers to treatment because of preexisting conditions. The public strongly opposes loss of these specific benefits. They also fear losing health insurance they obtain through work, as some health reforms propose. Yet this support is limited, not the kind of full-throated commitment that renders programs immune to attack. Commitment is limited by Americans fear of "big government." Between 1965 and 2017, Gallup has asked if "big business", "big labor", or "big government" most threatened the country. "Big government" is consistently the biggest threat, growing to $67 \%$ under the Trump administration. "Big business" is most feared by only a quarter of the public. ${ }^{1}$

1 Fishman, N., and Davis, A., "Americans Still See Big Government as Top Threat" news.gallup.com/poll/201629/americans-big-government-top-threat.aspx 
Those who seek more accessible, affordable, and higher quality health care need to move beyond the current political paradigm. Instead of simply focusing on the current system's inflated costs and other problems, they need to address the challenges of administering and managing a new system. That includes strategy to address inevitable political hurdles, as well as developing the capacity to run very large organizations. Programs that touch hundreds of millions of people must expand gradually. Political objections must be proactively managed.

For all Americans to get relatively low-cost and high-quality health care requires addressing the nation's realities. It's a big country (3rd or 4th largest in the world) ${ }^{2}$ with lots of people (3rd most.) Most of us don't recognize how important this is, in terms of administration of complex affairs. The US is passing through an interethnic gauntlet, as the majority ethnicity - white Americans of non-hispanic decent - falls below $60 \%$ of the total. Any social program with benefits for people with non-white or hispanic heritage, especially if benefits make a big difference for disadvantaged groups, will face harsh majoritarian opposition. On the other hand, as bad as commercially operated health care may be, a centralized bureaucracy may have very serious problems. Too often Americans look at small European health care systems as models. They need also observe larger countries like Russia.

Solutions emerge when it's recognized that America's division into 50 states is imperfect. Plenty of "red state” opposition to federal programs has to do with the incapacity of their meager state governments to shoulder burdens. To achieve success requires observing how other countries address decentralized health care delivery, namely regionally. Many states need to be grouped together under an administrative umbrella, so that properly delegated administration can function well.

This will happen deliberately, by seeding rollouts of "public-option” or "Medicare for All” type programs in multiple regions. These can grow, develop necessary capacities, and demonstrate potential. It will take time, as any program will need hundreds of thousands to millions of managers and benefit coordinators. This is common to all universal plans, including England, France, and Canada. Their scale is a fraction of the US, however. To manage a US system may require an organization that rivals the US military - a task to make any rational person pause. One rather radical alternative is to

2 It is unclear, when one includes territorial waters (rivers, lakes, oceanic borders) whether China or the US has a larger area. If China is larger, the US is the 4th largest nation. Otherwise it is the 3rd largest. 
nationalize US health insurers like United Health Group, and thereby obtain hundreds of thousands of specialized employees instantly. That no one considers this, while having no qualms about barring such companies from operating (and essentially putting them out of business) shows how little attention is given to administrative needs.

Any roll-out will take more than twice as long as the current "Medicare for All” plan intends. It will require sustained political effort. Contemporary politics will be difficult. Proponents will have to be clever. History shows that the US could now have more accessible, better quality health care. But perfection became enemy of the good, and reform was set back for half a generation. To avoid that, we need to face America's size, and its social realities, squarely.

\section{KEEP SCALE IN FOCUS}

Scale matters. At the smallest, things break down. Normal rules don't work. Quantum mechanics produces superpositions, entanglement, particle tunneling. Time and gravity are suspect. Of course, that's 36 orders of magnitude smaller than the mechanics of cars and toasters.

I'm the board member of a tiny school district, under 100 students, which is $10^{4}$ smaller than Los Angeles Unified. Normal organization rules break down at such small scales, replaced by psychological relationships. It matters less if teachers are constructivists, instructivists, or connectivists, and more what their personalities are. At this scale a single interpersonal conflict is ruinous.

Scale also matters at large scales. Herding animals can often survive environmental calamities like drought. But when herds get too large they degrade their environments. Scale improves health and survival up to a point, until the population itself becomes the story.

Increased scale usually requires diversity. The Argentine ant (Linepithema humile) is one of the most common invasive species in the world. It's distinguished from other ants by its lack of genetic diversity. Instead of local colonies fighting when they contact each other, Argentine colonies engage in kumbaya meetings. Huge supercolonies can form, spanning all of California, or most of New Zealand. However, homogeneous genetic systems don’t adapt well. As colonies pass some threshold of scale, their 
numbers collapse. Perhaps a pathogen or predator discovers a vast ant resource to mow through. Or genetic homogeneity leads to deleterious attributes, the ant version of inbred royalty. The lack of diversity that facilitated initial expansion also undermines it.

Mathematicians like scale invariance, or patterns that scale up or down without changing, like fractals. When processes and structures change their configuration, depending on how big or small they are, it's called scale variance. Human society is scale variant. At different sizes, different patterns and processes happen. Nearly every country's government, including the US, provides at least some health care to its public. Richer countries generally provide more than poor. But scale impacts how its done, in both.

American political culture is shaped by its large scale, particularly the politics and processes of health care reform. Scale impacts attitudes and habits. US homes, cars, guns, schools, and hospitals are shaped by it. American consumer behavior and medical consumption, is rooted in it. Because of its size and history, the US has high rates of internal mobility. That undermines tight-knit authority, and makes grassroots activism difficult. Geographic scale impacts organizational efficiency and effectiveness. The most comparable country to the US, in population and space, is, surprisingly, Russia. In the Americas, the country whose demographic and geographic scale the US most resembles is Brazil. We can learn from these countries, in ways that might surprise us.

There's a basic scale factor that I've identified that constrains organization scale. I call it the "Rule of Fives.” A formula shows how large organizations can become. There are absolute limits, at least during ordinary times. Ignoring scale impacts on bureaucracies is tantamount to inviting failure. This is a real danger, because scale is so overarching, it’s almost invisible. That's also true for Russia (and, naturally, it's easier to see in another country than one’s own.) When politicians tell people what they want to hear, scale isn’t mentioned.

Most nations subdivide into states or similar entities. That handles elections and administration. If scale didn't matter, subdivisions like states wouldn't be necessary. The US did much of its dividing while its European population rapidly expanded. States were sectioned off of larger territory, after a critical mass migrated in. There was more politics than planning involved. Old world subdivisions emerged in a 
more distant past, some to make sure hospitals and homes for old soldiers were in the right places. Scandinavian countries continue to reconfigure subdivisions, mainly to improve health care delivery.

The more a national government provides everyone's medical care, the more it becomes its major domestic function. Health care in large countries, particularly its administration, must be managed regionally. In the US, Medicare is delivered via groups of states. States are too varied, often too small or sparsely populated to sustain competent management. In the political discourse of today, it may surprise some people to learn that Medicare outsources all of its management to insurance companies. The map below shows the areas of each Medicare Administrative Contractor (MAC.)

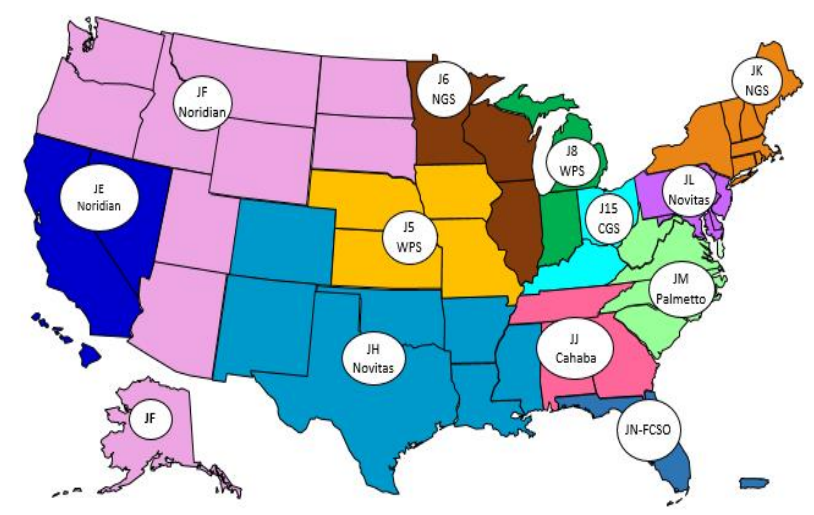

source: www.cms.gov

Federal agencies often organize regionally, not state by state. The IRS separates the country into 33 districts, each with 7 to 13 million people, in contiguous states (California and Texas are divided up.)

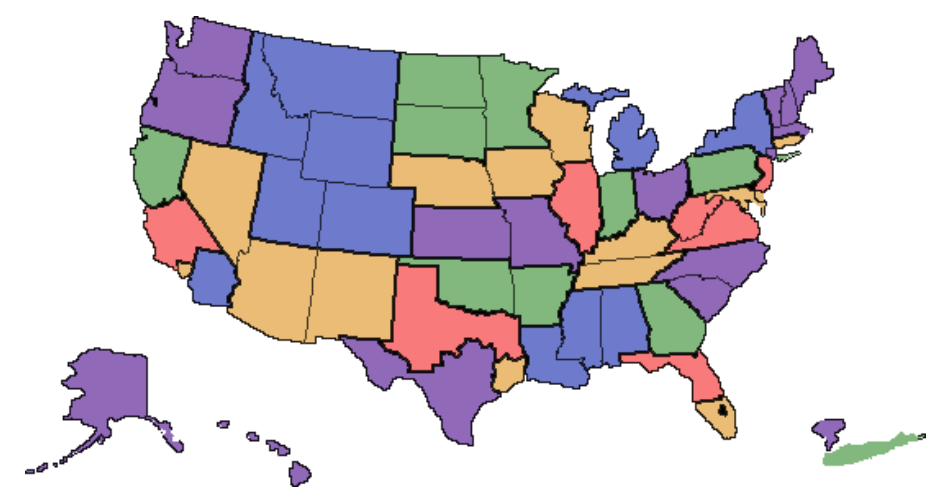

source: tracfed.syr.edu/help/geo/irsmap.html 
Given America’s size, rolling out a universal health care plan like the UK's National Health Service, or counterparts in France, Italy, or even Canada, will be a more than a big project. It would be collosal. Although its wrinkles were ironed out, the first years of the ACA's website roll-out skated close to disaster. This was a limited program for 12 million people, not hundreds of millions; the ACA was a portal for insurance, not a program managing complicated delivery systems. Countries like Britain or Italy have health care systems that deliver care like the US Veteran's Administration health care does, not US Medicare. Creating a national equivalent to the VHA system would require an organization that tracks and pays six to nine million employees. That's two or three times larger than the US Department of Defense, the world's largest employer. Many analysts believe the US military is itself too large to effectively manage, with operations too complex for existing accounting systems. ${ }^{3}$ The nation's medical delivery, provided through hospitals, HMOs, and clinics, with expensive machines and specialist MDs, making four billion prescriptions to millions of patients, whose sensitive, complex medical records are kept in regulated proprietary databases, is as complex as the military.

Many observers focus on the complexity of paying for US health care, not administering it. The usual story has two main causes: history and American governance. History starts with the different responses of allied powers to World War 2. European health care infrastructure was devastated. Governments had to provide medical services for their people. The US experience was different. During the war, with so many employees in the military, labor had leverage. That reduced the government's capacity to purchase ships, tanks, and planes, so it enacted wage controls. Employers used benefit packages, especially medical benefits, as a non-wage inducement to prospective workers. These became standard. After the war, the health care institution remained, unblemished. Employers got major tax deductions paying for health plans.

As for governance, the US federal government has difficulty passing legislation because of deliberate friction inserted in its Constitution. The founders united 13 colonies spanning 1,200 miles, at a time when transport was 20 miles a day by horse. At the time, of course, the issue of small and large states was a priority. Madison's solution forced provincial mind-sets and self-interests to enact legislation through processes that demanded compromise after compromise.

3 Committee on Homeland Security and Governmental Affairs, 2010, Improving Financial Accountability at the Department of Defense: https://www.govinfo.gov/content/pkg/CHRG-111shrg63833/html/CHRG-111shrg63833.htm 
The complex system of American health care, especially its funding, is said to result. Medicare includes three different payment systems, one based on Democrat proposals, another on Republican, a third from an American Medical Association (AMA) plan. ${ }^{4}$ The VHA is run like the UK's National Health System. The many commercial plans used by employers pay providers independently. The Children's Health Insurance Plan (CHIP,) signed into law in 1997, provides a block grant to states, which can expand Medicaid to children, or provide a state-level payment system. On top of these payers, each negotiating different prices, hospitals don’t reveal their costs.

Those who demand universal care gain attention during election cycles. This is when committed people and groups have an opportunity to make demands. After elections, their voices lose clout. The scale of the US makes it difficult for grassroots activism to mobilize large scale efforts in Washington DC. It's much easier for profitable institutions to organize nationally, and apply continuous, coordinated pressure. Throughout the $20^{\text {th }}$ century, the AMA would block reform. President Roosevelt dropped health coverage from the New Deal to avoid AMA opposition. As more women became doctors and more doctors work on salary for HMOs, the AMA took a back seat to other industries. ${ }^{5}$ Now opposition is led by for-profit hospitals, health insurance companies, and pharmaceutical firms.

Legislators retrench, and focus on tractable solutions. Campaign and lobbying contributions play a major role today, but this pattern existed even when money was more restricted. In the 1950s the Eisenhower administration wanted the federal government to provide universal reinsurance. It would cover 2/3 of any hospital bill over $\$ 1,000$ (\$10,000 today.) Conservatives objected at the cost. Liberals wanted more, but there was no national constituency clamoring for it. The next two administrations focused on senior health care, and a backstop for the poor. The decision to focus on the elderly was political. Seniors were a sympathetic group, and a voting bloc. The working poor became a surprising focus for conservative Democrats, to appease those wanting Medicare for the entire population. This appeared to be an issue primarily salient to the working poor. Medicaid was proposed to quiet them.

4 Oberlander, J. 2013. “Medicare: The Great Transformation.” In J. A. Morone and D. Ehlke, eds., Health Politics and Policy (5th ed.). Stamford, CT: Cengage.

5 https://www.wsj.com/articles/doctors-once-gop-stalwarts-now-more-likely-to-be-democrats-11570383523 
The 1993 Clinton health plan was an effort to provide both universal insurance and offset medical costs. The Clinton plan ran into full-throttled right-wing opposition and floundered. The administration turned its focus on children, with CHIP. Failing to reach a mountain peak, reformers compromise for an intermediate height. Each compromise increases overall complexity.

Lobbyists, partisanship, and legislative roadblocks aren't the only reason health care reform is hard. The uninsured population is skewed towards the historically disadvantaged, which undermines mainstream support. Also, existing infrastructure won’t disappear. Over-built and heavily financed hospitals will remain. So will powerful industries like pharmaceuticals, and overpaid doctors. Since all solutions involve compromise, many in the public don’t really like what they hear, either.

The friction that slows the legislative process, since not long after the constitution was ratified, is not a thousand small differences. Political parties, then slavery, finally race, became the overarching issue. This still stymies reform, yet health care reformers seem to misread it. Dog whistle policies like "states rights” are just words. Their proponents mean they want to discriminate like they used to, not run complicated government services at the state level. Reformers, generally Democrats, hear these dogwhistles, and though they may understand their intent, still believe they're a literal statement.

The call for “state's rights” doesn’t mean people in Missouri or Arkansas believe their state is particularly capable. They've heard propaganda to cut state taxes and services, and may agree. That certainly doesn't promote confidence in their state's ability to do things. They're angry that postindustrial development concentrates on coasts, and draws away their own best and brightest. That hardly encourages them to believe their state is equipped to run new programs. When the 1993 Clinton initiative or the ACA proposed that states manage health care (even if according to federal rules, and perhaps with federal aid), it’s not something rural red state Americans necessarily find comforting.

People want to limit federal oversight, not federal support. Does anyone in Wyoming believe the ACA's web-based exchange, if operated by their state, would be as useful as California's? The Clinton plan relied on states to collect all state health care premiums, to use for all health care plans in that state. Ignored was that such a program requires substantial administrative ability and significant employer participation. Opponents of the plan lived in states least likely to effectively run such programs. Not a 
message anyone wants to embrace, of course. Instead they dog whistle. Racial overtones are ugly, but they may camouflage concerns that the real beneficiaries of reform are, essentially, non-whites who live in large states.

When the ACA's health exchanges were rolled out, states could either run them on their own, get federal support, or let the federal government run it entirely. The map below shows few underpopulated states tried to run them independently.

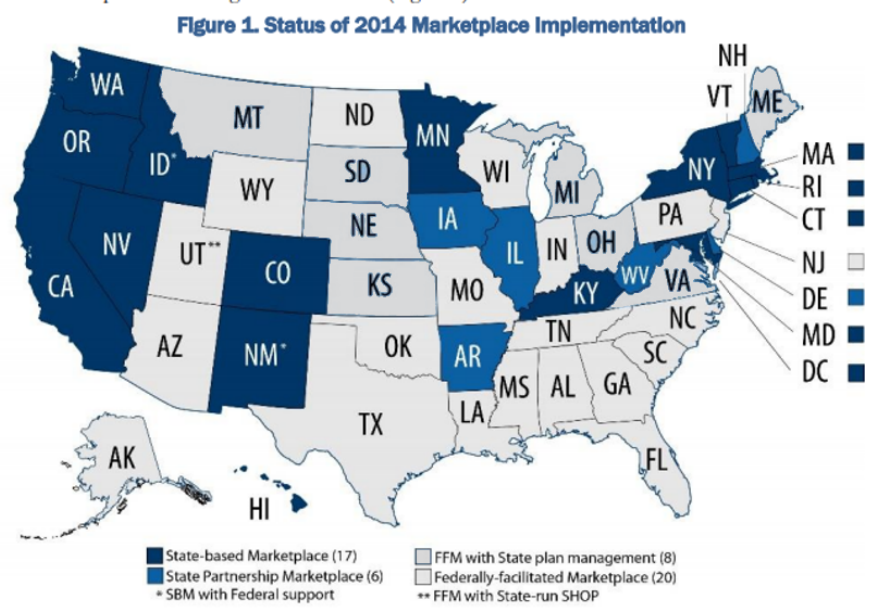

Clearly this coincides with partisan opposition to the bill, since Republican controlled states declined to run their own online exchanges. Yet another map, of states that expanded Medicaid, shows this was more than just partisan politics. Montana and North Dakota, and Nebraska and Idaho in 2019, are Republican states with limited populations that didn’t run exchanges but chose to expand Medicaid.

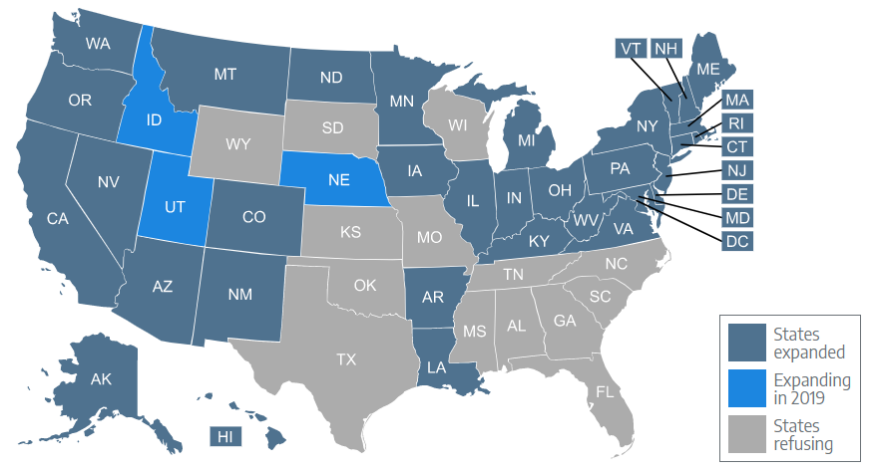

source: Norris, L., 2018. Medicaid expansion, eligibility, enrollment, and benefits. healthinsurance.org/medicaid 
A reason large, underpopulated states in the middle of the country are susceptible to anti-government propaganda could be, in part, an accurate assessment that their state government isn't very effective, while heavily populated states have both superior capacity, and the demographic density to obtain valuable federal attention. Devolving health care administration to underpopulated states puts them at a disadvantage, as does centralizing it in Washington DC.

It's also true that Republican oriented states that chose to expand Medicaid have primarily white working poor populations. It was those states whose likely new recipients were non-white that didn't expand it. This is an issue that deserves the slogan "black lives matter" as much policing, since nonexpanding states saw a five year excess death toll of around 15,600 Medicaid eligible people. ${ }^{6}$ These were predominantly the non-white working poor, in states where Medicaid expansion cost almost nothing. It’s hard to see this as reflecting a state’s concern for non-white lives.

The federal government spends quite a bit in a few sparsely populated states. But this "red state advantage" is exaggerated. Most of the prairie states get around the same amount of federal dollars as others. Some draconian Republican policies reflect the interests of their sparsely populated districts. Mass transit rarely impacts areas with fewer than 100 people per square mile, the areas Republicans dominate. Many GOP congresspeople reject any public spending on mass transit, while supporting highways. One could argue they're not nationalists, but the system is set up to force compromise.

Not considered is whether the division of US states makes sense. It's a common critique about other parts of the globe. The middle east and Africa are said to be badly divided into countries. In Africa there are over a thousand different ethnic groups (with different languages and cultures.) Borders slice some coherent groups in two or three, and leave others whole. Larger, intact ethnicities dominate politics; divided groups are disadvantaged. Conversely, two or more powerful ethnic groups are sometimes lumped into the same country, each wanting it's own nation. Instability often follows. The middle eastern case is better known, such as the cobbling together of Iraq, Jordan, or Lebanon with rival ethnic and religious groups. ${ }^{7}$

6 Miller, S., at al., 2019, Medicaid and Mortality: New Evidence from Linked Survey and Administrative Data, NBER Working Paper No. 26081, July 2019, Revised August 2019

7 Englebert, P., et al., 2002, Dismemberment and Suffocation, Comparative Political Studies, 35:10 1093-1118 
The US formation of states, after the initial 13, was done with little more care. Native Americans lacked any say. The first focus was on an area called the Northwest Territory. Three to five states were to be formed. A state needed 60,000 people, but most important was political agency to request it.

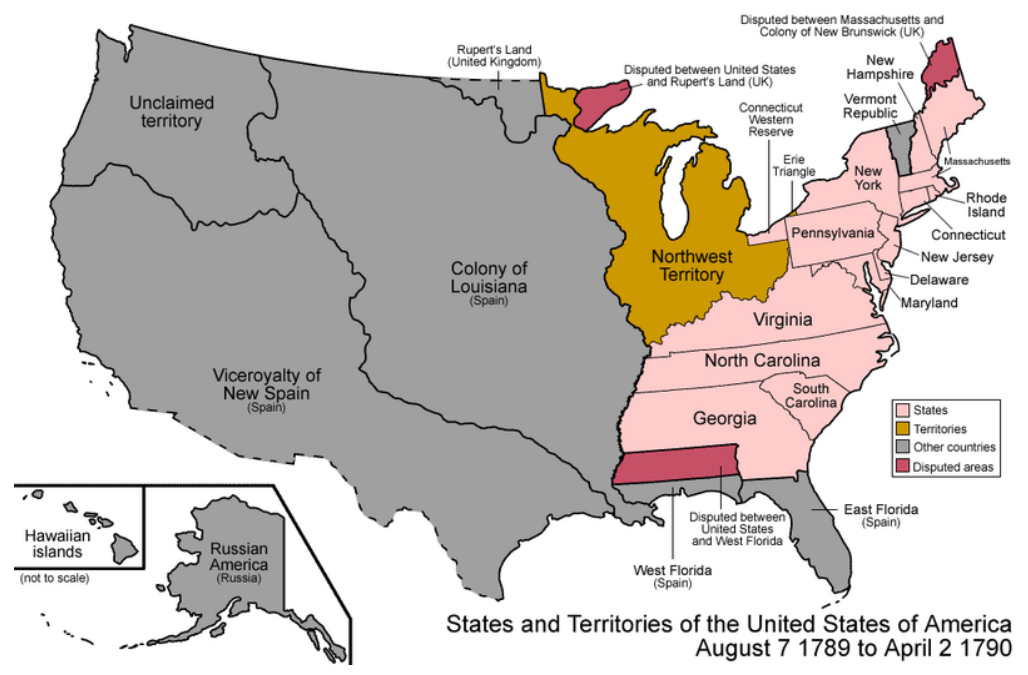

source: en.wikipedia.org/wiki/Northwest_Ordinance

Three forces kept states small. 1) States east of the Mississippi ceded lands to form new states, and didn't want these larger than the original. Antebellum Americans were keenly aware of being overshadowed by new states. 2) Migrants into new territories wanted to be bordered off from potential rivals, to maintain state control. Michigan Territory was carved out from Indiana Territory when a request for votes to elect Indiana's government arrived in Detroit after the actual election. 3) The balance of power between slave and free states led to a proliferation of each. The Louisiana Territory, renamed Missouri Territory after Louisiana became a state, had a southeast chunk become a slave state, Missouri, in 1821. Antislavery members of Congress blocked it, until an infamous compromise. For every new slave state, a new free state would enter. Keeping states relatively small helped keep the "balance.”8 The result of these multiple forces is that many American states, regardless of spatial extent, are too small to effectively manage what modern governments do.

A recent method uses the degree of straight-line borders to rank nations by arbitrary borders. Nonsquiggly, straight-line borders correlate with lower levels of development. ${ }^{9}$ US states east of the 
Mississippi have squiggly borders, suggesting they're derived from natural impediments or contrasting political forces. States carved from the Louisiana purchase and points west tend to have long straight borders. That suggests they're arbitrarily drawn by distant officials.

You build a healthcare program with the state lines that you have, not the ones you wished you had. The US has regions based on historical and cultural patterns. It also sliced into states that must be respected. Luckily, it is possible to group the country into five regions of about 65 million people each. That's the population size of successful European universal health plans. Within each, an administrative team can deploy resources much like today’s Medicare, which “touches” over 60 million.

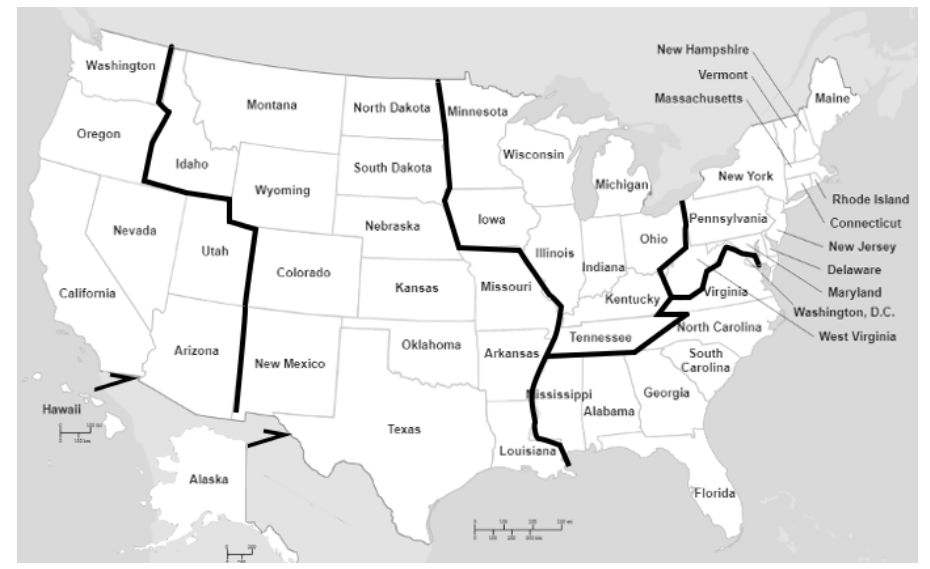

There are legitimate reasons humans can’t manage complex services for more than 100 million people. Some may believe the existing US health care system, however inefficient, demonstrates existing management capacity sufficient for centralized administration. This is myopic. The current patchwork includes many hospital systems larger than other nations’ entire health systems. Universal care proponents often present their ideas as “single-payer," “single-provider,” and "single health care player.” They should recognize that many Americans are threatened by the idea of centralized federal government.

The US federal government has a limited domestic footprint, compared to many other countries. But bigness is a fact of life for nearly all Americans. Social and physical conditions that encompass one's reality become background, ubiquitous. They shape attitudes, behaviors, and expectations. The inability of the federal government to provide important social services well may be a self-fulfilling tragedy, since the more people believe it can't, the less funding they support. But in the third or fourth largest 
country on earth, with the third largest population, it's not an irrational belief. There are 50 states, after all. The founders thought 13 were a lot.

In fact, a division of the US into five administrative regions probably exceeds the current capacity of federal health care delivery. This is partly a function of administrative realities, but also concerns national politics. In every country, a national program to provide services is a political process. The US is passing through a complex demographic period. In some areas there are critical amounts of ethnic diversity. This is a transitional problem, which should resolve itself in 15 to 20 years.

There are five themes I consider.

1. Scale impacts American society. This is usually taken for granted. But it's essential to understand, in contemplating almost any political or social change. The current "Medicare for All” bill seems almost oblivious to the demands of scale.

2. To organize a lot of people in a very large country is hard. That's true both for the establishment of a universal medical system workforce, and for the grassroots activism that must sustain a long roll-out. The option of regional organization has not been sufficiently considered.

3. The "Rule of Fives" is an equation that helps make sense of bureaucratic organization. People can manage four to six other people effectively. This forms a pattern, when repeated in organizations. It illustrates the capacity to organize large groups, and their constraints. There are reasons to respect the limitations on administrative size, as well as avenues to explore to overcome it.

4. The " $60 \%$ to $50 \%$ Gauntlet” describes a phenomena in which majorities damage society as their relative population reduces. I provide examples from the pre-Civil War south, California in the 1990s, and Brazil in the 1970s. This is not the only cause of ethnic fear and virulent outrage. But given the US white population in 2020 approaches 60\%, it’s significant enough to prepare for.

5. There are common ways that nations divide into state-like entities. There are enough similarities between nations, regarding state-like formation, that a country can learn a lot by examining what others 
have done. Scandinavian countries have reworked their regional divisions primarily for health care delivery. Even Russia provides an example of recent regionalization.

A conclusion follows, which provides a road map for a scale-based plan for health care reform.

\section{(1) SCALE, AMERICAN STYLE}

Americans are sometimes oblivious to how scale changes things in their society. The country's values, history, and institutions are considered more important. Consider the US military. It keeps the peace for global movements of goods, energy, services, and people. During the Cold War it was arrayed to prevent nuclear war. But in purely defense terms, the US, surrounded by oceans, with only two much weaker and friendly nations on its borders, is almost impregnable. The country could prevent invasion with less than half the military it now has, if that was its primary purpose. Many politicians understand that the relatively giant US military prevents hostile regimes from expanding their influence, stabilizes trade routes, and solidifies allied partnerships. Yet they rarely express this, worried the public will find them too oriented towards other countries' benefit. Instead they fall back on a sense people have that big is good. President Trump went so far as to reject the military’s foreign strategy, yet wanted bigger, larger armaments based on their cultural appeal. US geography helps explain this national characteristic. The same disconnect between scale's political impact and its influence on behavior occurs in Russia. Russians are hyper-conscious of their status, or lack of status, as a superpower. This despite a meager economy, a provincial culture, and limited public interest in global affairs. It seems to be a function of large populations in enormous spaces.

There's an old joke about a duck who says "how's the water down there” to two fish. They respond, of course, “what's water?” Perhaps nothing illustrates the influence of scale on Americans as norms about building size. We swim in a sea of big, bigger, and McMansion homes. Not only are US homes the largest in the world, a driving force behind rising health care and college costs is large building construction. These seem so natural, so essential to a properly functioning community, hospital, or university, they are accepted without criticism. 
People elsewhere notice. Another old joke, heard in plenty of European bars, runs "in heaven the chef is French, the policeman British, the home American, the engineer German, the wife Japanese. In hell the chef is British, the policeman German, the engineer French, the home Japanese, and the wife American.” This offends nearly everyone, but gets knowing laughter. One survey found UK homes average $33 \mathrm{~m}^{2}$ per person, Japanese $35 \mathrm{~m}^{2}$, French $43 \mathrm{~m}^{2}$, German $55 \mathrm{~m}^{2}$, and in the US $77 \mathrm{~m}^{2}{ }^{10}$ Other surveys find different averages, but similar trends, with Americans having the largest homes. Americans appreciate houses the way the French like food or the Germans cars. When surveyed, the only area the Americans rank highest on, among OECD life satisfaction indices, is their own housing.

America is indelibly imprinted by large scales. Only $17 \%$ live in apartments or condos; $53 \%$ want to live "away from it all."11 Yet Americans don't believe that the scale of things shapes them. The hubris required to send people to the moon required the most powerful rocket ever built, the Saturn V (after 50 years still the biggest.) In contemporary American consciousness, this massive fact, on display in various museums, is ignored. Instead debate concerns whether the tiny lunar module failed to kick up moon dust, thereby revealing a giant conspiracy. "We're not really that big," conspiracy theorists seem to be saying.

Large suburban houses are attributed to zoning laws, transport systems, FHA mortgages, segregation, economic conditions, a baby boom, aggressive contractors, and weak local governments. These all matter, but most intersect scale: zoning giant suburban lots starts with having expendable space, and the ease of spreading suburban housing made automobiles more useful than trains. Cities like London, Frankfurt, and Copenhagen saw a vast expansion of suburbia after 1970, but none on the US scale. Sprawl consumes land, and land is scarce in Europe. Los Angeles initially epitomized the low-density metropolis, a city of suburbs. But it's ringed by mountains and deserts, and could expand only so far. Had LA only rolling hills and green landscapes to the east, it might stretch all the way to Las Vegas. ${ }^{12}$

10 http://shrinkthatfootprint.com/how-big-is-a-house 112011 Community Preference Survey, National Association of Realtors builderonline.com/money/economics/80-percentof-americans-prefer-single-family-homeownership_o 12 Moura, M.C.P., et al., (2015) 120 Years of U.S. Residential Housing Stock and Floor Space, PLoS One, 10(8): e0134135 
Sprawl occurs when property values further out are less than those further in. Houses are less expensive when more people build them. Post-war America mass marketed power hand tools. Contractors hired a vast pool of inexperienced workers and built cheaply quickly.

Americans demand front yards, but they're not unique in this. Demand needs supply, and its big countries like Canada, the US, and Australia that have abundant land for lawns. Between 1950 and 1995 Chicago's population grew 48\%, while land covered by residences grew $165 \% .{ }^{13}$ Pine forests spread around Atlanta, until cleared for suburbs. There’s so much available, 31 million forest acres may become single-family housing units by $2040 .{ }^{14}$ Few other countries have that much forest to cut.

Forests were spread so thickly across colonial North America that it's said a squirrel could run from the Atlantic ocean to the Mississippi without touching ground. As settlers moved inland, they cut trees and farmed. The tree abundance was so intense visitors expected to find a roaring fire in a farmer's hearth. ${ }^{15}$ If not, it was a sign of laziness. Ambitious farmers were expected to use things up and migrate west. Conspicuous consumption was a sign of hard work. It was culture driven by a lot of land.

US gun culture is "frontier" mentality. People on newly demarcated land, surrounded by a vast continent, were isolated and afraid. An endless forest or prairie needed a gun.

Americans value larger cars and drive farther. Compared to 11 other "advanced democracies," they drive nearly double the average distance per car, per year. Canada is closest, where vehicles travel 8,200 km per capita. In the US each car travels 13,000 km. ${ }^{16}$ Commute distances are important, as are distances between cities. Both are larger in a bigger country. Crossover SUVs became the most commonly purchased automobile in 2018, pushing sedans to second place. Spatial perception is important. Larger cars let occupants see farther. For the king of the castle, it’s the commanding heights.

13 Greene, R.P., and J.M. Harlin, 1995 "Threat to High Market Value Agricultural Lands" Social Science Journal, 32(2): 137-155

14 Wear, D.C., 2002, Land Use and Timber Outlook, samab.org/wp-content/uploads/2011/06/2002-ProgramAbstracts.pdf p54

15 H.C.M. Scott, Fuel An Ecocritical History, Bloomsbury Academic, 2018, p.36

16 pdf.wri.org/automobile-fuel-economy-co2-industrialized-countries.pdf 
Larger cars fit more children, while American family size shrinks. US home sizes increased the most in the last 30 years, when persons per home decreased. ${ }^{17}$ The US has the largest pig, dairy, and cattle farms in the world, when Americans are eating more calories than they need. ${ }^{18}$ But while the US has the highest obesity rate (of countries over 10 million people) big farms don't cause it. ${ }^{19}$ Big farms are possible in a big country, where conspicuous consumption is a sign of hard work. Big homes are possible in a big country, where big homes are a sign of status. The common thread is size.

US education culture rejects, as a norm, control by the federal government. In other OECD countries education is more centralized, controlled and funded by the national government. The US federal government is too distant to be in charge of something so intimate. It's the same in other big countries. English public schools are governed by the national government, Australia’s by the local state.

A national health care database, with every residents' medical records, will run up against this. Health history is personal and intimate, not something to gathered in Washington DC.

The biggest expense in US health care is hospital costs. A large part of hospital costs is facilities. The average patient room size in the U.S. increased from 240 square feet in 2002 to 320 square feet in $2012 .^{20}$ The average bed occupancy of other developed countries was $76.1 \%$ in 2016 . In the US, occupancy was 62.9\%. ${ }^{21}$ The US spent \$36 billion in 2006 on new buildings and extending existing hospitals, a 33\% increase from 2003..$^{22}$ In 2015 it spent $\$ 97$ billion, a 266\% increase from $2006 .{ }^{23}$

According to a Bank of America report, "Capital spending drives market share in the hospital industry.” ${ }^{24}$ Non-profit and profit hospitals are compelled to build larger, more impressive buildings, which is accomplished by charging patients more than necessary to secure financing. Yet according to McKinsey, “US provider systems have a considerable amount of capital tied up in what are now

17 U.S. Department of Housing and Urban Development and U.S. Department of Commerce, 2015 Characteristics of New Hoursing, census.gov/construction/chars/pdf/c25ann2015.pdf

18 www.oecd-ilibrary.org/docserver/5jlv81sclr35-en.pdf?

19 worldpopulationreview.com/countries/most-obese-countries/

20 Luoma, H., 2014, Best of 2014: Increasing Patient Satisfaction By Decreasing Patient Room Size, healthcare design 21 Sahni, N., 2019, The productivity imperative for healthcare delivery in the United States, McKinsey \& Company 22 healthcare.mckinsey.com/sites/default/files/MGI_Accounting_for_cost_of_US_health_care_full_report.pdf 23 healthcarefinancenews.com/news/top-healthcare-construction-projects-2015-buidling-surges-demand-picks-revista-says 24 Bank of America Annual Hospital Survey, 2015 
unproductive fixed assets. ${ }^{25}$ Hospitals in countries where governments pay for hospital buildings have much lower costs. They also don't have such large hospital buildings. They are also smaller countries.

During the run up to the 2020 Democrat Presidential nomination, several candidates, and many voters, supported “Medicare for All” legislation. Senator Bernie Sanders wrote a bill by that name, co-signed by four other Presidential hopefuls. It's a list of health needs that must be covered at no cost to citizens. Three single sentences describe administration: the federal unit in charge will plan for expenditures and services; it will plan doctor and nurse education funding; it will help states develop plans. No details are offered. A section titled “Regional Administration” establishes regional directorates, which, if possible, incorporate the CMS regional office. This is the only mention of how administration is structured, and suggests it will use the Medicare regional arrangement. These are highly unequal regions, incomparable in population and income, an unfortunate basis to serve 327 million Americans.

CMS Medicare programs are delivered in 12 geographic jurisdictions. Each area has very different Medicare populations. Jurisdiction H contains 13.5\% of total Medicare A/B recipients, while Jurisdiction 8 has 5.9\%. Since 2003, CMS does competitive bidding for MAC selection. They're concerned about scale. In 2010 CMS tried to limit the jurisdictions a single MAC could contract for. They didn't want to award over 26\% of the national A/B Medicare population to any single contractor, or more than $40 \%$ to a single contractor's affiliates. A Federal Appeals panel overruled them.

Other than the mention of CMS regions, the Sanders bill follows a state-level orientation. The national budget determines administration, capital, and education expenditures, and each state is responsible for execution. 1\% of the budget, which could be $\$ 30$ billion (1\% of $\$ 3$ trillion) may be used to assist health insurance workers displaced by the bill. According to 2018 Insurance Information Institute figures, there are 507,100 medical insurance employees. ${ }^{26}$ This number doesn’t include a similar number of plan administrators who work in health maintenance organizations. For just the insurance workers, the bill provides about $\$ 60,000$ each. Their expertise is ignored, though potentially invaluable to rolling out a massive new program.

25 healthcare.mckinsey.com/sites/default/files/MGI_Accounting_for_cost_of_US_health_care_full_report.pdf 26 https://www.iii.org/presentation/insurance-industry-employment-trends-1990-2018-january-2018-030918 (Note that a Google search returns the health insurance industry hires 2.66 million people. This is incorrect.) 
The Sanders plan has a four year roll-out. In year one the Medicare age lowers to 55, year two to 45, year three to 35, then presumably it's Medicare for all. The bill offers no explanation for why these age groups are selected. In 2017 there were 41.65 million Americans between 55 and 64, and 83.32 million between 35 and 54, according to the US Census. Thus around 40 million people join the rolls each each, tripling Medicare's population to over 180 million. According to the Sanders bill, the transition is run like Medicare. Although they aren’t mentioned, presumably MAC insurance companies must massively increase, integrate a million new employees, establish systems and vast hierarchical bureaucracies, over three years. Their roles after that, when Medicare for All kicks in, is not explained.

The bill, in pdf format with wide margins and oversize text, runs 100 pages. Formatted like this article, it's 35 pages long. It would be considered bare bones and of little functional use in a country like Norway, with 5 million people. The bill that established the ACA was criticized for being over 1,000 pages, as was the failed Clinton health plan. Their lengths reflected the demands of actual implementation. Without addressing the massive scale of the US, its population, the size of its medical infrastructure, the Sanders bill isn't grounded in reality. That it has gathered so much attention, often uncritical, including enthusiasm from millions of supporters, demonstrates the American penchant for ignoring the scale and diversity around them.

Proponents of the Medicare for All legislation point to Canada as a model. What's commonly ignored is its regionalization, which has fostered incremental innovation, not sudden major reform.

Although Canada has so many fewer people than the US, because they're spread out over such a large area, it suffers some similar issues. Universal health care was passed in Canada in 1966, but quality deteriorated towards the end of the 20th century. A 2001 review found "task forces, commissions, and policymakers charged with strengthening primary care have almost always advocated "big bang” reforms - the universal, more or less simultaneous, implementation of an "ideal” model." The authors concluded "the pursuit of "big bang" change under unfavorable circumstances may not simply be futile but may result in missed opportunities for cumulative incremental change."27 
Canadians are spread out and have a strong feeling of independence. Prior to the 21st century, there were many parts of the country where physicians worked in small groups or alone. A top-down plan didn't sit right with many. These feelings can be found in the US as well. When provincial governments, working with provincial medical associations, developed their own autonomous healthcare organizations, funding methods, and payments, genuine innovation and reform happened. ${ }^{28}$

Provincial governments fund primary health care services. The money is actually transferred from the Canadian federal government's general revenues, through The Canada Health Transfer (CHT), a scheme developed in the early 21st century. It's a block grant, but must be used to meet national healthcare criteria. The CHT is based on population (though until recently provinces with less robust economies got more.) Provinces can also raise their own taxes to supplement healthcare.

Different provinces organize health care differently, because they hold the purse-strings. In Quebec, many family physicians serve in groups of six to ten. Ontario organizes it's family medical groups in teams of ten to 30. In Alberta they work in groups that average about 60. Quebec tried the larger, interdisciplinary approach, but physicians opposed it. Provinces have different priorities, and different health care outcomes. But Canadians are receiving more effective care. In 2002 only 600,000 people in Ontario had a primary physician. By 2011 that number rose to 9.5 million. ${ }^{19}$

Canada has a smaller population than California, by about two million. So it bears none of the demographic scale of the US. But it's geography is immense. That is sufficient to drive a certain type of health care path. Reform failed when the country’s scale wasn’t recognized, and “big bang” solutions were borrowed from Europe. It would seem the US is still caught in this phase.

\section{(2) THE NEED FOR PEOPLE TO RUN THINGS}

Through much of the $20^{\text {th }}$ century, US workers migrated from one part of the country to another at higher rates than other countries. Employers dramatically relocate without leaving the country. Employees move to different latitudes, where living conditions can be completely different. European political norms, like labor supporting socialist parties, need groups of people in concentrated networks. 
The ubiquity of internal migration in the US lets the air out of politically charged unions. Spatial mobility, which can exploit distance in big places, defeats organization.

The US ordinarily functions on two primary levels, one nation-spanning, one state-level. People distrust Washington DC, a federal government composed of a tiny fraction of the national population. It's burdened by distance, separated by an entire continent from the nation's biggest economic engine, California. No other country in the world has it's economic center and finance and government centers so far apart. It’s as if Vladivostok was the economic powerhouse of Russia.

When national protests occur, demonstrations in Washington DC are center stage. It's extraordinarily unlikely that people from California, Texas, or the state of Washington can be present in numbers that represent their state sizes. The US Constitution is clear that public demonstrations are important for democracy, that in modern terms they serve to speak truth to power. Yet the scale of America dilutes that, damping popular efforts to change major policies.

Beatrix Hoffman noted that grassroots campaigns, essential for movements that changed conditions for workers, women, African-Americans, and seniors, rarely mobilized for universal medical care. ${ }^{29}$ She observed that health reforms emerge among experts in elite institutions, while grassroots activists demands are more urgent and immediate. Unlike factory workers or working women, who spend 10 hours a day reminded of conditions that need changing, health care needs arise infrequently. But Hoffman misses something. Grassroots activism that changes national policies makes its voice heard protesting in Washington, DC and New York City. That's a very high bar for movements in a big country, because people live far away.

Prior to 2016, seven of the ten biggest marches in US history were in Washington DC, two were in NYC. Politics is a social contest, and nothing rivets attention, from the media, the public, and especially elected officials, like mass protest on their doorstep. The point of demonstrating is to push the problem into the face of the most powerful leaders, who aren't in San Francisco or Chicago. The juxtaposition of protesters with Washington's monuments or New York's towers galvanizes the public. 
Recent protest marches against the Trump administration, the Women's Marches and Marches for Science, as well as the gun reform protest March for Our Lives, occurred in many cities. They're still anchored in Washington DC, where their leaders speak, and largest crowds assemble. But protest leaders now encourage marches in multiple cities around the country. Organizers recognize the difficulty of reaching the nation's capital.

Decentralized protests are what a grassroots movement for universal health care may accomplish. Gun control, after all, is a public health problem. Decentralization can weaken reform, because it reduces protest concentration in the capital. For example, as many as five million people joined the 2017 Women's March, making it the largest in history. 200,000 to 500,000 marched in Washington, DC, ${ }^{30}$ almost as many in NYC, ${ }^{31} 150,000$ in Boston, 250,000 in Chicago. ${ }^{32}$ The largest group may have been in Los Angeles, where 100,000 to 750,000 marched. ${ }^{33}$ The contemporary policy domain, for many reasons, generates enough interest to mobilize many city protests, not a gigantic national one.

If five million people show up in Washington DC they can demand almost anything, and probably achieve a breakthrough. That power is lost when spread out to many cities. If Boston, NYC, and Philadephia selected one city to march in, they would have reached 800,000. Had just these northeast marchers joined Washington DC, they would have had 1.3 million. That would have been the largest single city demonstration in history. If San Francisco, Sacramento, and Los Angeles settled on a single city, they would have easily broached a million. It's not part of an American mindset to organize regionally. But if there were four or five regional marches of around million each, it could break into the national consciousness in a way city protests do not. This "regional” mindset needs development.

Americans believe they can reinvent themselves, largely because they can relocate somewhere completely different. Instead of being indivisible, they can be invisible. In this way Americans are like people from other large countries, and not the rest. Most of the world's people live in smaller countries.

30 www.washingtonpost.com/local/womens-march-on-washington-a-sea-of-pink-hatted-protesters-vow-to-resist-donaldtrump/2017/01/21/

31 www.dnainfo.com/new-york/20170121/midtown/trump-protest-womens-march-nyc;

32 www.chicagotribune.com/news/ct-womens-march-chicago-0122-20170121-story.html

33 abc7.com/news/750000-attend-womens-march-la-organizers-say/1713822/ 
If protesters have more power when they concentrate in bigger numbers, workers tend to lose power when institutions concentrate as larger entities. The operations of California's landline telephones were summarized to me by a lineman who had worked on them for several decades. He saw PacBell become SBC become AT\&T. Each change saw levels of organization grow, and policy became more opaque. Today's AT\&T has so many levels that he solves problems by taking a work order and "losing" it, then doing what's obviously necessary. His supervisor covers things up, because with so many levels of administration, there's too much paperwork for anyone to monitor. The lineman's ethical code keeps him honest, even if he does what he wants. At least that's what he said. He can't vouch for others.

Bureaucracies operate through hierarchies. The larger these are, the less transparent they become. Those high up in the hierarchy can't see down to the bottom. Those on lower rungs can't see to the top.

Huge countries have this problem. From abroad, China looks like a draconian big-brother state. But with 1.3 billion people, the central government rules through layers upon layers upon layers of lower level cadres. Citizens can escape rules by convincing or corrupting local officials, who pay attention to demands of those on levels directly above, not eight levels higher.

China, despite having the second largest police force in the world (India has the largest,) ranks around 130th out of 142 in police per capita. Each policeman in China serves 869 people, each policeman in the U.S. serves 358, and each in Russia serves $158 .{ }^{34}$ Even if India or China wanted a police system like Russia's, they couldn't run one. India would need 8.24 million police, $4{ }^{1 / 3}$ times more than today. China would need 8.63 million police, nearly 5 1/2 times more than now. These forces would be vastly larger than any organized security forces in the world. Such a large police force would have so many layers of bureaucracy it might grind to a halt.

China developed a Confucian culture to run a big place, deliberately avoiding excess bureaucracy. In the late tenth century, the early Northern Song government bureaucracy had only 3,000 to 4,000 ranked officials, who governed a population of about 300 million. ${ }^{35}$ It operated by monitoring local authorities,

34 en.wikipedia.org/wiki/List_of_countries_and_dependencies_by_number_of_police_officers 35 Department of Asian Art, 2000 "Scholar-Officials of China.” Heilbrunn Timeline of Art History, New York: The Metropolitan Museum of Art 
possible because strict social hierarchies captured local gentry and local clerks. The Chinese population was fixed, visible, and bound by status. When people can't hide, they are much easier to control. That seems to be the ambition of the current Chinese regime. But it isn't possible. A “big brother” security state of China's size can monitor aberrant behavior. If people meet and organize in buildings for legitimate reasons, they can do so for reasons not deemed legitimate without standing out. China's monitoring apparatus is primarily operated by central authorities to monitor other powerful people, because it is these they can control, whom they are threatened by.

Medicare also operates with only a little more than 4,000 administrators. They do it by outsourcing management to the MACs. Administrators can monitor and try to control key MAC executives, not the MAC workforce. MAC workers reimburse hospitals and doctors, pay for pharmaceuticals and medical equipment, and have call centers where Medicare participants find out benefits, make appointments, choose doctors. Their disbursements follow Medicare rules, using Medicare dollars. Medicare covers $1 / 2$ the health care costs of 60 million people this way.

The Medicare for All proposals supported by several Democratic candidates in the 2020 Presidential primary are unclear on MACs. The government is the payer. But is it just the administrator, like Medicare? Or does the government reimburse hospitals, pay for drugs, and serve customers, like the VA's health system, the VHA? The Sanders bill only states that enrollees "are entitled to have payment made by the Secretary,” which, combined with its ban on insurance companies, sounds like VHA. Running the whole country's health care like the VHA would require setting up an enormous operation, bigger than the US military. The problem isn’t just cost. How will so many people be hired, administered, and managed?

To estimate a "VHA for All” employee total, I used the VHA's own disaggregation of patients into 8 categories, called priorities. Veterans in priorities 1 to 6 are older, poorer, sicker. They use 85\% of the VHA budget. Other vets, younger, healthier, are categories 7 and 8. Half don't receive appreciable services in a given year. It's difficult to assess their per capita costs, because the total budget includes overhead. The VA itself estimates it spends between $\$ 1,000$ and $\$ 6,000$ on different types of users in categories 7 and 8, but doesn't offer an average. ${ }^{36}$

36 VA Priority Groups Qualifications www.payingforseniorcare.com/longtermcare/resources/veterans_priority_groups.html 
Categories 7 and 8 don't use 15\% of the budget, but they may use 15\% of VHA employees, 45,000, or 64 veterans per employee. This is better than the UK's National Health Service, where each employee serves 42.1. The NHS serves the elderly as well as others. The entire VA Health Care population, including sick and old, requires an employee for each 30 veterans.

There are 272 million Americans not in government medical programs now. If every 64 need an employee, VHA for All would have 4.25 million employees on its payroll. The NHS has, depending on information source, between one and 1.6 million. ${ }^{37}$ At the NHS rate, the US would pay between 4.92 and 6.46 million, midpoint 5.69. However these numbers include hospital staff and doctors, all those who deliver care, as well as the government administrators and managers. Between 3\% to 5\% of NHS employees are direct managers. 4\% at American scale would be 227,700. In 2008, 16\% of the workforce was part of "NHS infrastructure," customer service and administrators. At the US rate, given 5.69 million total Medical for All workers, that number is 910,400.

The total government employees required for Medicare for All, structured like the VHA or NHS, might be around 1.14 million.

Figuring how many employees are required for a Medicare for All, structured like today's Medicare, is more complicated. Medicare has a good reputation is because its core parts A and B, which provide hospitalization and doctor payments for around 38.5 million people, have very low overheads. But to figure out how many workers they use is more difficult. Some data suggests MACs use 500 to 1,000 employees per state. ${ }^{38}$ If so, that's 30,000 and 45,000 nationally, a very efficient rate of one employee per 1,000 Medicare recipients. Medicare reports 86.1\% of Medicare claims are filed electronically, or 139 million claims filed on paper. That could explain workforce efficiency, but it implies the total number of Medicare claims is 1.2 billion, when they are actually about twice that number.

In a footnote ${ }^{39}$ I calculate estimates for MAC employee totals. The figure is probably between 30,000 and 90,000, all efficient rates of 425 to 1,200 Medicare customers per MAC employee (midpoint 812.)

37 K. Grosios, et al., 2010, Overview of healthcare in the UK, EPMA Journal, 1(4): 529-534 38 dailykos.com/stories/2019/4/16/1850694/-Big-MACs-Meet-the-7-private-insurers-who-d-grow-larger-w-out-actuallyinsuring-anyone-under-M4A 
“Medicare for All” using insurance companies would not hire managers, as does VHA for All, although Medicare A/B programs provide only 55\% of Medicare services. Extended nationally to all Americans, that 55\% would need around 400,000 employees.

According to the CMS 2019 annual report, administration costs for Medicare Parts A and B are historically small. "The ratio of administrative expenses to benefit payments has generally fallen within the range of 1 to 3 percent.” This includes MAC expenses. Part of the low figure is due to the higher cost of older people who use Medicare. In 2014, Medicare spent \$10,926 per beneficiary, while overall US per capita spending was $\$ 9,523$. Distangling the part of that overall spend that was on Medicare, Medicare total spending was $62 \%$ of commercial plan spending. Commercial plans insured four times as many customers in $2017 .^{40}$

Thus Medicare spent $21 \frac{1}{2}$ times more per capita, which dilutes administrative costs. For the general population, Medicare A/B would run around 4\%. ${ }^{41}$ This is similar to Germany or Australia. It's considerably less than commercial insurance administrative costs, which are $10 \%$ to $20 \%$. There's a caveat. Medicare Part C comprises about 45\% of Medicare recipients. Instead of "fee per service," as Parts A and B are operated, Part C is provided by HMOs and other commercial providers. Part C may control overall costs better than A and B, but it has a much higher administrative cost component around 14\%. This may be due, in part, to the inclusion of HMO fees in Part C administrative costs. Hospitals incur the kinds of administrative costs that insurance companies do, namely billing process, but its only a fraction of their total administrative costs. ${ }^{42}$

39 According to one source, electronically filed claims save around \$3 per claim, compared to paper filing. One estimate places computer costs at around $\$ 8$ per claim, which seems high. I'll assume they cost $\$ 5$ per claim, and paper claims $\$ 8$. MAC employees are not well paid. Perhaps with benefits and other employer costs, a company spends $\$ 20 /$ hour per claims processor. That would suggest the worker processes 2.5 claims an hour. If the total number of claims is two times 139 million, or 278 million, that's about 110 million hours of work. Given a full-time worker clocks around 14,400 hours a year, it would only take 8,000 total employees to process that.

No one works 60 seconds a minute, 60 minutes an hour. One study found office workers spent $2 \frac{1}{2}$ hours a day on dedicated tasks. Another reported the most productive employees worked $75 \%$. The real productivity of MAC employees who work on claims processing is at best $50 \%$. That bumps their numbers up to 16,000 . Claims processors make up perhaps $20 \%$ of MAC employees. Figured this way, there are 80,000 total MAC employees.

40 https://www.census.gov/library/publications/2018/demo/p60-264.html 41 https://www.kff.org/medicare/issue-brief/the-facts-on-medicare-spending-and-financing/ 42 Bentley, Tanya G K et al. "Waste in the U.S. Health care system: a conceptual framework.” The Milbank quarterly vol. 86,4 (2008): 629-59. doi:10.1111/j.1468-0009.2008.00537 
The Medicare population's higher expenses could also mean this $14 \%$ would be higher for the general population, although some HMOs use “capitation,” rather than paying for services. Part C may have about four times higher administrative costs, serving 45\% of Medicare services. It seems reasonable to assume that Medicare Part C, extended to the whole country, will need around 725,000 employees. Together with Part A/B workers, “Medicare for All” using MACs will need around 1.125 million employees. If they cover all of the US, that's 290 Medicare employees per person.

Medicare for All structured like the VHA or NHS, and Medicare for All structured like Medicare, both may need a similar number of new government workers, a little over one million. That is twice the number of employees hired by the US healthcare insurance industry today, but including HMO managers and administrators, today's total is around 1.2 million, serving a smaller population than Medicare for All would. That's because the roughly 28 million Americans without insurance who would get coverage, as well as CHIP and other programs that would fold into it.

Under either Medicare for All flavor, a government workforce channels \$3.5 trillion to hospitals and other providers, requiring institutional fortitude no government or company has been tested on. Currently state-level workers manage funding, within and apart from programs. According to the Urban Institute, in 2017 US state and local governments spent 10\% of expenditures on health and hospitals, and around that much on Medicaid. Medicaid is folded in to public welfare expenditures, which account for $22 \%$ of total budgets. ${ }^{43}$ State and local governments hired 422,579 health-related employees in 2019 and 885,900 hospital employees. There are also 1 million managers, some of whom operate Medicaid and other healthcare-related programs. Regardless of their source of funding, they provide necessary work.

These people will operate a universal healthcare program. It would serve five times as many people as today. It seems possible that four million new state hires will be needed. This would be the largest expenditure and biggest hiring need of the program. They would be distributed across the states, however. It's likely that hiring shortages would emerge in some states.

43 State and Local Government DataQuerySystem, The Urban Institute-Brookings Institution Tax Policy Center. Data from US Census Bureau. 
In Canada, provincial government workers channel money to providers. Around 900,000 Canadians work in provincial government health and social service institutions. This includes public services for housing, job assistance, but most deal with health care. The same commitment in the US would require eight million state workers to channel money and operate programs.

Canada is not a great example for the US. First, 2018 total healthcare spending in Canada was \$253.5 billion, $\$ 162.5$ billion from public sources. ${ }^{44}$ That's only 3.3\% of what's spent in the US. Second, Canadian federal and provincial governments hire 19.9\% of all Canadian employees, while US federal and state governments hire 15.8\% (both 2014 figures.) If US governments hired 19.9\%, they’d have to put 12.7 million more people on the payroll. Many developed countries have larger public payrolls than the US, where public employment is not well respected. ${ }^{45}$ The UK hires $21.5 \%$, France $24.9 \%$, Australia 18\%. Some nations have lower rates, like Germany’s 12.9\%. We should look at what they do.

Germany has the oldest "universal" health care system in the world, surprisingly similar to a wellfunctioning ACA. The Germany state chose to regulate rather than engage in direct provision of care. That reduces the government's administrative load. Each year a commission, with representatives from medical industries, other businesses, and unions, determines the upcoming year's total expenditures. Health insurance is compulsory for everyone, and everyone has it. Those who earn less than $\$ 67,575$ per year are automatically enrolled in a non-profit insurance fund. These are managed independently, but must stay within the commission's parameters. Employers and employees each pay 7.3\% of the worker's salary for it. No actuarial adjustment is made for age or health status. Most Germans who earn more than $\$ 67,575$ also enroll in these funds, which cover the whole family.

Countries like the UK and France are comfortable with a larger role for government employees. The British government employs most of the people who work in the healthcare sector, and pays for hospital buildings and equipment. It's funded by general tax revenue. France has a system midway between the UK and Germany. Health insurance is compulsory, but is operated by the government

44 cihi.ca/en/health-spending/2018/national-health-expenditure-trends/who-is-paying-for-these-health-services 45 Lerman, A.E., Good Enough for Government Work, Chicago Studies in American Politics, 2019 
(unlike Germany.) It costs about $\$ 11 /$ month for $100 \%$ coverage. ${ }^{46}$ In Paris doctors can charge three times more than the reimbursement rate, which must be covered by the patient. The system is paid for with a $12.8 \%$ tax on business earnings, and a minor income tax.

Given the penchant of Americans for limited government, a plan like Germany's (an ACA with teeth) may seem the best fit. It's reasonable to assume that in countries where more people work for the government, a significant portion of them are involved in managing the healthcare system.

Any government health care system that serves the entire US population will involve over one million new federal hires, and perhaps four million new state workers. A successful roll-out will take many years. Questions of equity will be raised, since a long roll-out means some areas and some people get service before others. This is a strong reason for starting in many different locations at the same time, and expanding. The following map shows a division of the country into five areas with about the same population in each.

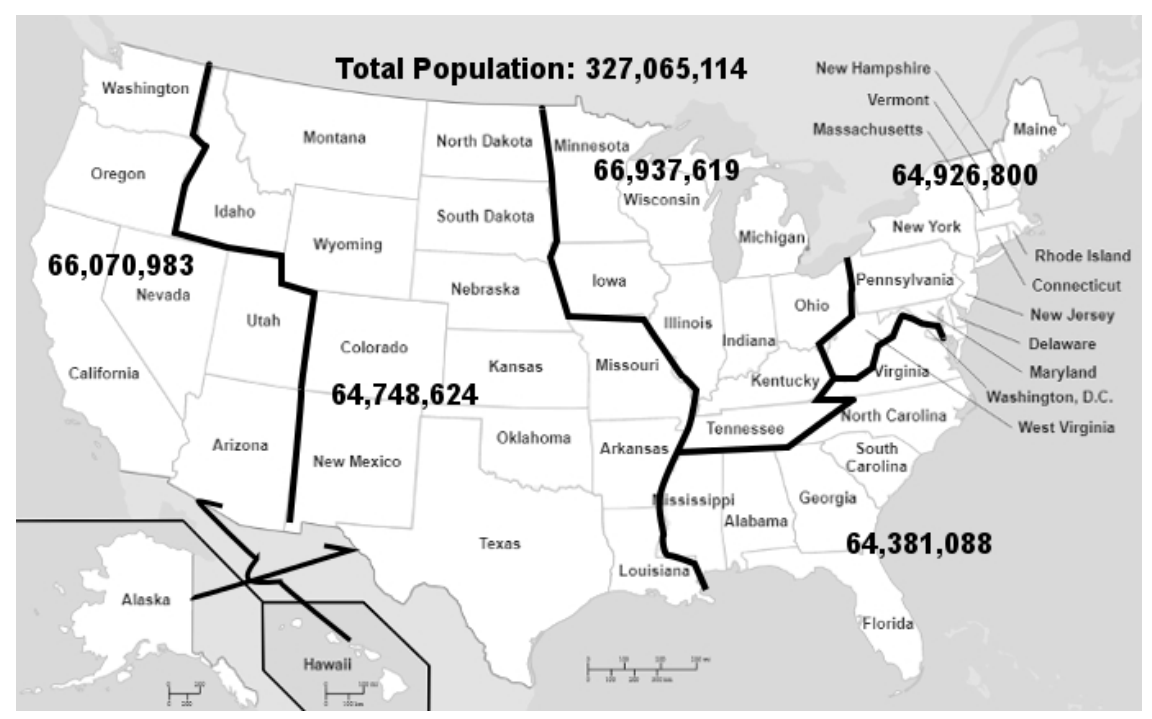

Five equal regions

An intermediate level of administration, at a regional level, can address the needs of sparsely population states as well well as more populated ones. Regional boundaries should resemble cultural,

46 Deluxe plans for \$110/month offer maids and babysitters to keep up one's lifestyle when in the hospital. 
political, and economic regional aggregations. Five regional areas would be large enough to avoid overly partisan manipulation. Each has about 65 million people to serve, the current Medicare size.

Keeping state lines intact, five regions can be delineated, three with 65 million people, two with 66. They're what you'd expect: Northeast, Southeast, Midwest, Prairie, Pacific.

The need to regionalize healthcare delivery is not unique to social change in the US. Political manifestations, including those pursuing universal healthcare, must increasingly focus on regional assemblies, rather than in every city. Other elements of governance, including elections, may benefit with partial regionalization of processes.

\section{(3) THE 'RULE OF FIVES'}

Organizations are not unlimited in size. People can reliably supervise four to six other people. If they are supposed to have charge over many more, most administrators stumble. It may be a matter of time management, of cognitive overload, of the tendency of people to veer from expected behavior. Some of it is due to the need for redundant communication, which requires time. This heuristic principal of administrative load can be called the "Rule of Fives.” Certain organizational constraints follow.

If governed in a top-down manner, the Rule of Fives generates an exponential growth of the governed, $0.239 \cdot(\mathrm{e} \cdot(1.616 \cdot \mathrm{x}))$, where $\mathrm{x}$ is the number of hierarchical levels. An organization with 10 levels could, in this view, govern about 21/2 million; with 11 levels, 121/2 million; with 12 levels 63 million; with 13 levels 317 million; with 14 levels, 1.6 billion; with 15 levels, 8 billion.

These totals correspond to certain human organizational phenomena. The largest employers on the planet, the U.S. and Chinese militaries, contain around 21/2 million people. The largest in history were the U.S. and Soviet militaries during WW II, which had about 121/2 million each. The U.S. Medicare system (60 million) and the British (65), Italian (61), and French (67) universal health care systems serve an average of 63 million people. The next levels correspond roughly to the U.S. total population (327), the projected future population of India (1.68 billion) which will likely be the largest population 
any country achieves for many years, and the world's population in around 2030 (estimated to be 8.6 billion.)

Organizations do not rule in strictly top-down manners. Instead they form silos, which introduces redundancies. Many people have assistants. Headquarters have their own groups. Specialists have roles that don't configure into tree diagrams.

Nevertheless, a Rule of Fives hierarchy corresponds to the number of employees in canonical institutions, suggesting something about how human organizational capacity scales.

There's evidence that the largest employer in the world, the U.S. Department of Defense, exceeds some conventional threshold of manageability. It employs 2.86 million personnel. A military organization may appear simpler to operate than a business, on one level, because incentives are formal. But soldiers need room and board, technology continuously evolves, and the services (army, navy, air force) are fiercely independent. As the U.S. military has grown, so has it's tooth to tail ratio. The teeth are combat-ready troops, the tail are support. In 2011, the tooth side made up $17 \%$. This compares to $26 \%$ in a survey of 28 other countries (and doesn't count the contractors the military uses.) U.S. military departments use up to $20 \%$ of their budgets to coordinate their own activity. It's easy to advise them to use central administration. But examples, giant corporations like Walmart, are smaller and much simpler.

The basic US army structure is notable for it's levels of organization. The Army Group is the highest tactical level, with seven or eight levels beneath it (field army, division, brigade, battalion, company, platoon, squad). ${ }^{47}$ Each level has its own headquarters units and certain specialties. What's interesting is that from the bottom-up, employing the "Rule of Fives" produces the same numbers as each higher level. The Pearson Coefficient value of their correlation is 1, too good to be true, so it probably is.

47 CBO, 2016, The U.S. Military's Force Structure, cbo.gov/sites/default/files/114th-congress-2015-2016/reports/51535fsprimer.pdf 


$\begin{array}{lrr} & \text { Army } & \text { Rule of } 5 \\ \text { squad } & 8 & 6 \\ \text { platoon } & 30 & 30 \\ \text { company } & 150 & 153 \\ \text { battalion } & 1000 & 771 \\ \text { brigade } & 4000 & 3883 \\ \text { division } & 15000 & 19541 \\ \text { field army } & 90000 & 98350 \\ \text { army group } & 500000 & 495196\end{array}$

What this means is that the army group, seven levels of hierarchy above a squad, coordinates roughly half a million personnel. It would appear that at each level the organizational structure has one individual in charge of five at the next lower level.

There are only 1.3 million troops in the four services. To this are added 826,000 National Guard and reservists, and 732,000 civilians. In the army, there are about one half million each on active duty and in the reserves. Each branch, and each active and reserve operation, has an independent hierarchy. They each duplicate high-level management functions. This is common among conglomerates. BP, an energy conglomerate, had 11 levels of hierarchy when Tony Haywood became CEO in 2007. ${ }^{48}$ He apparently cut four levels out, perhaps too many, since three years later the Deepwater Horizon explosion revealed BP had limited oversight of contractors. Mergers most often fail because of failure to blend top management, not lower-level workforces. It's not a problem of big egos unable to get along. If two companies are a good fit, then its mainly high level management who duplicate efforts. This occurs between the US military's branches, too.

The US military may be highly capable, but no accounting system is sufficiently flexible and scalable to manage it. ${ }^{49}$ This isn’t hyperbole. A basic attribute of any organization, especially one that processes $\$ 700$ billion annually, includes a systematic accounting. Big accounting programs exist for this very purpose, used by very large corporations, for example. They simply do not scale to the US military’s size and complexity. Media reports headline the DOD’s budgetary fudging and misreporting, but that

48 Times Online, Sept. 25 2007, BP to strip out four layers of management, business.timesonline.co.uk/tol/ business/industry_sectors/natural_resources/article2527470.ece

49 Paltrow, S.J., Aug. 19, 2016, "U.S. Army fudged its accounts by trillions of dollars, auditor finds," Reuters 
misses the point. It's like complaining how someone very nearsighted takes pictures out-of-focus. The problem is scale. It's possible that a step-wise reduction in size, perhaps $2 \%$ at a time, could be tried. A pause at each slightly lower level would permit both adaptation and review.

It's not clear why systems with 10 or 11 levels approach a human maximum. It seems self evident that 100 levels would be too many, but why 11 ?

If each level interprets, implements, and communicates a message from one level above, then a hierarchy is like a game of telephone. I assume a message must be at least $50 \%$ coherent to be meaningful. In a hierarchy there's a cost in interpreting it incorrectly, so under 50\%, there's more value in ignoring the message. Once messages are ignored, the benefits of organization break down.

It only takes about a 7.5\% loss of fidelity at each of nine levels below the first, to end with a just above 50\% accurate message at the bottom level. A 92.5\% fidelity rate is much better than what normally occurs during any communication. Research suggests people only remember about $50 \%$ of a message immediately after hearing it, eight hours later that drops to $35 \%$, two months later to $25 \% .{ }^{50}$ However, if the message is repeated over carefully spaced periods of time, memories of it increase to the $70 \%$ level. ${ }^{51}$ Perhaps appropriate repetition is the secret to managerial success. This may explain a reason for the "Rule of Fives." A manager could communicate a message to many more than five people, even individually, but the need for redundancy reduces that.

Oversight of the US health care system is a significant task. There are 16,866,020 people in the sector. ${ }^{52}$ 2,590,770 work in medical offices, 3,401,900 in nursing and residential care, and 5,232,630 are in dentists offices, other health practitioners, outpatient centers, diagnostic labs, home health services, and other ambulatory care. ${ }^{53}$ Most are under the umbrella of Medicare for All. 5,640,720 work in hospitals.

50 Kramar E.J.J., and T.B. Lewis, (1951) “Comparison of Visual and Nonvisual Listening,” Journal of Communication, November, p. 16

51 Roediger, H.L., and J.D. Karpicke, (2006) "The power of testing memory: Basic research and implications for educational practice,” Perspectives on Psychological Science, 1(3) 181-210

52 www.kff.org/other/state-indicator/total-health-care-employment/

53 www.bls.gov/oes/current/naics4_621100.htm; www.bls.gov/iag/tgs/iag623.htm; www.bls.gov/iag/tgs/iag621.htm 
In 2017 there were 931,000 hospital beds in the US, in 7,200 hospitals, an average of 130 beds. There are many small clinics that bias the average. 200 beds is a typical or median hospital size. The Bureau of Labor Statistics estimates that about five million people were employed by hospitals in 2016, an average of 694 per hospital. According to Beckers Hospital Review, 597 full time and 257 part time employees typically work at a 200 bed hospital.

Hospitals must be accredited, resourced, staffed, operated, financed, and monitored. A government team may be able to oversee two 200 bed hospitals. Their directions and feedback are under the authority of a group that controls three oversight teams. These are under area authorities, who are under semi-regional ones. These, in turn, have regional directors, under a federal administration. 7,200 hospitals require 3,600 oversight teams, coordinated in 1,200 groups, under 300 area authorities, and 100 multi-area ones, and 50 higher level ones. Above them are semi-regional (perhaps 10) regional (5) and federal overseers. Eight heirarchical levels. If each unit has 20 people, 100,000 staff.

In 2010, one study found an average residential care facility had 24 beds. ${ }^{54}$ Another study in 2001 found average-size nursing homes had 107 beds. ${ }^{55} \mathrm{~A} 2013$ study put the number at $108.6 .{ }^{56} \mathrm{~A}$ government funded system would need to dedicate a team to oversee every two facilities with 100 beds. But because of logistics, no team can handle more than four, even if they're small. In 2010 there were 51,367 licensed residential facilities. If we assume an average team oversees three, the result is a pretty frightening nine levels of oversight management. This could require 400,000 government personnel. Perhaps this is why so many scandals occur in residential care.

There are about 600,000 doctors in the US, in about 50,000 medical groups. ${ }^{57}$ Medicare for All will need to deploy seven levels for this sector, about 100,000 people. Twice that many will be required for the dental, outpatient, lab, and other ambulatory care organizations. The Rule of Fives analysis suggests about 800,000 government workers are needed to run an entire Medicare for All system, if it takes a hands-off approach to service providers. However this doesn't include the back-end systems, customer

54 R. Mollica et al., 2010,"Assisted Living and Residential Care in the States," INSIGHT on the Issues, AARP 55 Wunderlich, G.S. and P.O. Kohler, (2001) Improving the quality of long-term care, Washington DC: National Academy 56 American Health Care Association Quality Report, 2013, ahcancal.org/qualityreport/Documents/ 57 Bloniarz, K., (2016) "Physician Affiliation and Practice Size”, Medpac 
service, and other personnel. Again we end up with at least one million people, for a system that leaves existing health care companies to operate much like they do now.

Some politicians have proposed a "public option” plan, run by the federal government, that would be a low-cost, adequate benefit insurance plan. The concept for a public option was developed by academics in the early 2000s. Most of these ideas retained state-level payment structures, as would the ACA. Some, though, proposed a one stop national-level public option plan. It was estimated, in 2002, that if plans extended to all who wanted them, 100 million might join. Today, given shrinkage of the employer insurance market, that number could be 150 million. It might trigger a cycle of commercial insurance retrenchment, followed by more public option growth. Yet academics didn’t deeply consider how administering a "single payer" option to 100 or 150 million people would work. A national "public option” would be a single government plan.

The largest commercial health insurer is currently UnitedHealth Group, with almost 50 million commercial subscribers. It also covers another 20 million for supplemental Medicare and Medicaid services. UHG is the largest health care company in the world by revenue, ranked 6th on the 2019 Fortune 400, with 300,000 employees.

A public option could mean the federal government replaces UHG's services, presumably at lower cost. Their CEO is the leading opponent of "Medicare for All.” But though this for-profit company maximizes premiums, it offers something of a model for a "public option” roll-out.

UHG, originally a Minnesota insurer, began expanding in 1994, to Florida ( 20 million,) in 1996 to Arkansas, Maryland, Kentucky and Tennessee ( 20 million,) in 1998 to Arizona ( 7 million,) in 2001 New York ( 20 million,) 2002 New Jersey and Pennsylvania ( 20 million,) 2003 Maryland, Washington D.C., Virginia, Delaware and West Virginia ( 18 million,) 2004 Wisconsin and Connecticut ( 10 million,) 2005 Colorado and California ( 35 million,) then overseas. The numbers in parenthesis are the states total populations, of which UHG only serves a fraction.

It's notable that the general population of states per year of expansion is fairly consistent. It took about a decade for UHG's mostly-national coverage to complete. The chart below makes an arbitrary 
assumption that UHG obtained half the population of each state it entered. Although very imprecise, the final total is roughly equal to its current market share.

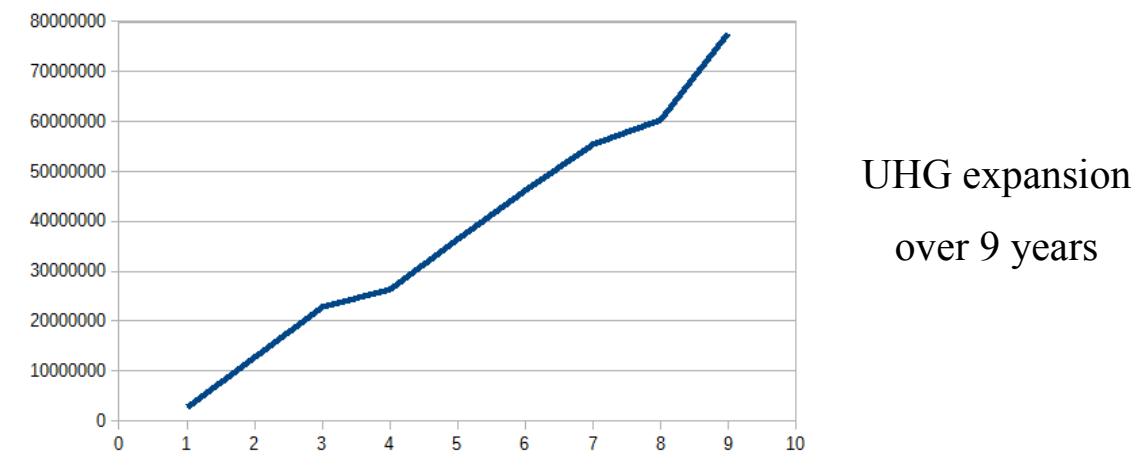

Given 250,000 UHG employees serve 70 million customers, each employee serves 280. An annual growth of 10 million new customers required bringing on board 36,000 new employees each year. That required at least seven levels of bureaucracy for each group, an organizing requirement greatly facilitated by expansion through the purchase of existing companies. It's possible that an organization that grows by acquisition can escape the "Rule of Fives” constraint, if it allows the acquired organization to operate independently.

The US government could, in theory, purchase insurance companies outright, and thereby gain hundreds of thousands of experienced employees. No one has suggested this, because the debate over health care has focused on costs and services, not administration.

When governments purchase a company's assets and operations, it's called nationalization. Nationalized companies become government bureaucracies. If the company sells things on the open market, nationalization usually fails. The insurance company American International Group (AIG) was nationalized by the Federal Reserve and federal government during the financial crisis. They sold it four years later, for a hefty profit. Of all industries to nationalize, insurance may pose the fewest contradictions. Most insurance markets are determined by statistical analysis. They don't involve commercially driven design needs, mechanical engineering, complex retail operations, even much product development. Their most important function is to retain sufficient capital, or have reinsurance arrangements, to cover losses. And of course staff negotiate with beneficiaries and others. 
Any plan to banish the existing health care insurance industry should be compared to nationalizing it. A lot of the services that health insurers perform, such as negotiating hospital costs and determining patient needs, will still have to be performed, even if insurers don't exist. The data that insurers collect and analyze will continue to be needed, to plan how to deploy resources. Insurance employees are not simply dead weight, they have valuable skills and knowledge. Insurance companies are not like tobacco companies, they perform a public service. Putting them out of business by fiat is not particularly fair. Purchasing them at fair market value is an interesting alternative.

Nationalization won't expand health care, simply replace the commercial provider of tens of millions with a government one. But given the simplification of policy and payments that should occur under the government program, insurance employees could become more productive. More importantly, they could enable the rapid expansion of a public option that the public will demand. Expanding it 50\% annually needs 40,000 or more new employees each year. If these employees were obtained from existing insurance firms, the federal government could provide them new operating rules, but allow the cohort to operate independently, even under previous lower-level management.

Many people would find a ten-year roll-out of the program unremarkable, except for the fact that it's supposed to provide everyone with the same services from day one. Which states would be earliest? This inherent lack of fairness would cause opposition. It took seven years for the US Border Patrol to increase from 11,000 to nearly 22,000 agents. It took nine years for the Transportation Safety Administration to deploy 60,000 agents. A “public option” for all who want it may require a federal workforce over ten times that large. It might take well over a decade to roll-out.

Of course, if a public option was combined with putting insurance companies out of business, then potential administrators, managers, and employees may become available. But a public option is supposed to supplement existing insurance. Eliminating insurance would instantly require the government to administer solutions for 327 million people. 
(4) THE 60\% TO 50\% GAUNTLET.

The US pioneered universal white male suffrage, the right of white men to vote. Though initially limited to men owning sufficient land, that was quickly expanded along with the country. Some popular accounts claim only "6\%" of US white males could vote in the early 1800 s, a myth derived from superficial histories of Andrew Jackson (that make him out to be the "great populist" who expanded voting.) The most important force driving universal white male suffrage was the nation's growth. Six of the ten new states formed in the early 1800s established it from the start. Instead of Jackson causing expanded voting rights, he was its result: those new states were his strongest "base”.

Meanwhile, all the new states (except Maine in 1819) banned free blacks from voting. New Jersey and New York had originally granted free blacks the right, but after 1800 rescinded it. Other states implemented formal bans. As white male suffrage was promoted by the growth of America, blacks and women were suppressed. In 1776 New Jersey made history by granting women the right to vote, but in 1807 the state extinguished it.

By scaling larger without increasing voter diversity, the young country set itself on course for a civil conflict. Since the Cold War era, studies consistently find democracies rarely have civil wars. Semidemocratic nations, on the other hand, have the highest rate of internal conflict of any form of government. Rather than deducing how undemocratic the US was in 1820, what's notable is that it doesn’t fit the statistical pattern of democracies that do have civil wars. Hegre found, using international data on $20^{\text {th }}$ century civil wars, that democracies usually avoid them once their per capita GDP is above $\$ 700$ annually (1995 dollars.) ${ }^{58}$ The US had a per capita GDP well above this through its entire national history, reaching around \$2,240 in 1860 (1990 dollars.) ${ }^{59}$ By excluding AfricanAmericans, native-Americans, and women from de-jure power, early America opened the door to repression and violence to silence opponents. The country's growth, which opened areas without European inhabitants, was an invitation to people to flee repression and generate discontent. People denied democratic rights were aware of democratic norms.

58 Collier, P., et al., Breaking the Conflict Trap, World Bank, Washington DC, 2003

59 Lindert, P.H., and J.G. Williamson, (2011) American Incomes 1774-1860, eml.berkeley.edu/ webfac/cromer/e211_f12/ LindertWilliamson.pdf 
A common reason given for the US Civil War is that both sides eyed the new territory, west of the Mississippi to the Pacific, through an economic lens. Each wanted to impose its economic system, slave-based or free, because members of each side didn't want to compete with the other. This textbook economics is questionable. Northerners might expect to migrate into a more southerly western state one day, but a long-term future economic constraint is a weak reason to die in a war. People knew that wars (in the $19^{\text {th }}$ century) were death zones. Because of the War of 1812 (the US version) Americans were very aware of Napoleon's disastrous Russian campaign. There was widespread anxiety that the British, freed from worrying about the French, would redouble their efforts against the US (in fact the British were exhausted.) Napoleon was understood to have not merely lost, he lost catastrophically. People understood this was what modern $19^{\text {th }}$ century war meant. ${ }^{60}$

Even if mobilization is seen through rosy glasses, these weren't naive people. Southerners should have been even less inclined to fight. Only $1 / 2$ of $1 \%$ of whites in slaveholding states had slaves! Of those who did, most owned one, not enough to compete with slave holding plantations. Only 2,341 plantations had 100 or more slaves, a minuscule portion of the white population. Rationally, southerners had powerful economic reasons to want to migrate out of slavery's shadow.

The reason white populations in the antebellum south volunteered to fight had to do with demographic change. A pattern can be observed in different areas of the US through its history, and in different countries of the world. When the dominant ethnic group’s population total falls below $60 \%$, a substantial portion reacts harshly. Very conservative, unfair policies are promoted. Democrat norms get violated. If democratic institutions are in place, and the suppressed minority can accumulate assets, the situation improves once the dominant group falls below 50\%. Both democracy and assets were missing for African-Americans in the antebellum south.

In 1790, the white population in slave states was $64 \%$ of the total. South Carolina had the lowest percent, 56\%, and through the antebellum period was the state most egregiously hostile to national change ${ }^{61}$ In 1860 , across the south, the white total had fallen, though it's complicated by new states

60 Bukovansky, M. (1997). American identity and neutral rights from independence to the War of 1812. International Organization, 51(2), 209-243. doi:10.1162/002081897550348

61 faculty.weber.edu/kmackay/statistics_on_slavery.htm 
with small populations. ${ }^{62}$ The original slave state white population fell to $60 \%$. South Carolina's white population was 41\%, Georgia's was 56\%, new state Alabama had 54\%, new state Louisiana 53\%, new state Florida 56\%. South Carolina, the state with the smallest relative white population, was first to succeed. When ethnic majorities fall below $60 \%$ of the population, a significant part of it becomes fearful. It wasn’t economic self-interest that drove southerners to fight in the Civil War, but racial fear.

California experienced this pattern during the 1990s. In the late 1980s, the state's white population approached 60\%, then fell below it. The political center veered rightward. Undocumented immigrants were barred from public schools and hospitals, and other laws made their lives difficult. Affirmative action was repealed in referenda. Perhaps half of California's white voters were truly fearful. Voting as a block, they controlled politics for a decade.

But early in the 2000s the white population's percent in the state fell below 50\%, then continued lower (it is now 37\%.) ${ }^{63}$ Below 50\% the fearful half of white voters were too small to determine elections. Like a toy ship pushed down by a thumb bobs up when released, California's politics righted themselves. Non-white Californians remember the political groups that hurt them, and together with the half of the white population that wasn't afraid, now control the state. In time the state's politics may shift towards political parties that are both multi-ethnic, but for now only one of two is.

The wealth of ethnic groups interacts with their numbers. The role of African-Americans in the US is undermined by more than their minority status. Systematically denied asset accumulation, blacks face major barriers in obtaining education, safe housing, and starting businesses. But non-whites in California are primarily Latino and Asian. A careful study of Los Angeles found that most Asian groups, who are almost half the population of whites in LA and California, have more assets than whites, per capita. ${ }^{64}$ Latinos, who are slightly more numerous than whites in the state (and considerably more in LA) had much fewer assets than both. This complexity, which may not be present in the entire US, dampens the capacity of the dominant ethnic group to control power. California did not disenfranchise minorities, as other states have done.

62 www.civil-war.net/pages/1860_census.html 63 Adele M. Hayutin, A.M, et al., (2011) "Understanding California's Demographic Shifts, Stanford Center on Longevity 64 De La Cruz-Viesca, M., et al., 2016, The Color of Wealth in Los Angeles, San Francisco, Federal Reserve Bank 
Nationally, Americans of Latino and Asian heritage are the fastest growing population groups. Across the entire country, a “60\% to 50\% Gauntlet” may follow a trajectory seen in California. In specific regions and states, however, African-Americans make up the most significant minority group. States that have a history of Jim Crow and racial suppression will delay a resolution to the gauntlet, even after the white population diminishes to under $50 \%{ }^{65}$

The US is part of the New World. Most other New World countries are much smaller and less populated. Two exceptions stand out, Canada and Brazil. Canada is a poor comparison for US demographic dynamics. It has 1/9 the US population, with much less diversity. Canada’s black population is about 3.5\%, and Latinos number less than $1 \%$. Asians account for $17 \%$. Canadians of European ancestry make up over $75 \% .{ }^{66}$ Perhaps this helps explain the apparent tone-deaf behavior of Canadian Prime Minister Trudeau, who as a young man wore black-face to parties.

Brazil has $64 \%$ of the US population, in a country $87 \%$ as large. At first glance it seems to have very different ethnic dynamics. In Brazil, people with both black and white ancestry are called multiracial or "pardos," which means brown. (The US “one drop rule” defines the same person as black.) The percent of both whites and blacks keeps falling, while multiracials gradually increase, to now over $40 \% .{ }^{67}$ But in important ways, Brazil does resemble the US. Wealth is distributed predominantly to whites, who earn twice what both multiracials and blacks do. Brazil also suffered a "60\% to 50\% gauntlet."

Brazil's military leaders overthrew the elected leaders of the country in 1964, as the white population fell to $60 \%$. The military dictatorship censored all media, tortured, murdered, and exiled dissidents, and reduced wages for the poor. ${ }^{68}$ By the mid-1980s the white population had fallen to about 50\%. Many forces were at work undermining the dictatorship, which ended in 1985. But the fact remains that the Brazilian power structure, largely white, lost its demographic dominance. Once elections were reestablished, a new majority asserted itself, promoting policies that helped the country advance. Recently a populist reactionary government was elected. Brazil’s wealth remains entrenched among

65 Perez, A.D., and C. Hirschman, 2009, The Changing Racial and Ethnic Composition of the US Population, Population Development Review, 35(1): 1-51

66 en.wikipedia.org/wiki/Demographics_of_Canada

67 https://www.worldatlas.com/articles/largest-ethnic-groups-in-brazil.html

68 Klein, H.S., and F.V. Luna, Brazil, 1964-1985, New Haven: Yale, 2017 
those of European heritage, so they can still control the political narrative. But Brazil went through a far more wrenching political period when the white population transitioned from $60 \%$ to $50 \%$.

After the dictatorship fell, a universal healthcare provision was established. Anyone in Brazil is served without charge. But private health insurance and private hospitals and doctors are used by professionals and other middle class and wealthier persons. These make up 25\% of medical consumers, but 2/3 of Brazil's hospitals, and $87 \%$ of its specialized hospitals, serve the private sector. ${ }^{69}$ This is a function of Brazil's economic condition, but also a result of the pent-up demand for reform. After the "gauntlet" period the free system was demanded, despite being under-resourced and over-worked. It doesn’t work well. A colleague of mine was in a rural Brazilian area, and had a medical problem. She went to a free hospital, waited many hours, and saw a doctor for five minutes. He dismissed her illness. She then made an appointment with a private hospital, and a doctor spent half an hour with her, diagnosing and prescribing a cure. What was so notable to her was that it was the same doctor. He didn't remember her from the day before, having seen so many patients in the free system.

Brazil's system claims to have the largest free healthcare service in the world, with over 50,000 clinics distributed over 3.3 million square miles. It "only" employs 642,027, a function of its limited service capacity. ${ }^{70}$ Certainly Brazil's scale, like the US's, makes a national program difficult. Unlike programs developed gradually and carefully, it’s over-centralized and bureaucratic. But given Brazil’s ethnic dynamics, which induced great hardships during the 1970s, an idealistic reformation was inevitable.

The histories of the antebellum US, of California in the 1990s, and of Brazil between 1960 and 1985, show that when the dominant ethnic group, in these cases European whites, falls to around 60\% of the population, stuff happens. Politics takes a nasty turn towards right-wing retrenchment. Rational policies are rejected, if they serve more than the dominant ethnic group. Once that population falls below 50\%, things can return to relative normalcy. But a high degree of ethnic repression can trigger an idealistic surge when the situation changes.

69 healthmanagement.org/c/icu/issuearticle/the-overview-of-healthcare-in-brazil 70 en.wikipedia.org/wiki/Sistema_\%C3\%9Anico_de_Sa\%C3\%BAde 
Between 60\% and 50\% may be a "red zone" of racial anxiety. The 2020 US census will find that the nation's white population falls to $60 \% .{ }^{71}$ In US states along the Pacific ocean, whites are already less than 50\%, and rational politics have reemerged there. In the southeast, European-Americans have fallen to $59 \%$. In Texas, they've fallen to $43 \%$. In most other states white populations are above the "red zone" threshold.

A national plan will suffer because the entire nation is in the thrall of white fear. If rolled-out regionally, programs will face opposition from those areas within a gauntlet “red zone.” These areas include states that refused to expand Medicaid under the ACA, because it would have served many non-white people.

At the same time, the US lacks the necessary health care administrative experience to field five distinct regional programs. By dividing each 65 million region in half, the subdivisions can more easily gain experience. Coincidentally, the Prairie and Southeast regions will be divided so that half have much less, and half much more, ethnic diversity. The same thing happens with the other three regions, primarily because white Americans dominate less populated states. When a region is divided in half, it's usually the largest state (California, Texas, New York) on one side, and remaining states on the other. The largest states may be sufficiently diverse to minimize racial fear. The less populated states haven’t reach the tipping point yet.

When states have more than $60 \%$ white populations, they are less opposed to rational health care policies. This can be seen in the decisions of states to expand Medicare. Midwestern states under Republican leadership, whose poor populations are largely white, expanded Medicare even though, as partisans, these leaders ostensibly opposed it. States in the south and southwest, whose working poor include large numbers of blacks and Hispanics, refused to expand Medicare. This despite the fact that states didn’t bear Medicaid costs, but their hospital emergency rooms would cover uninsured victims.

71 www.census.gov/quickfacts/fact/table/US/IPE120218 


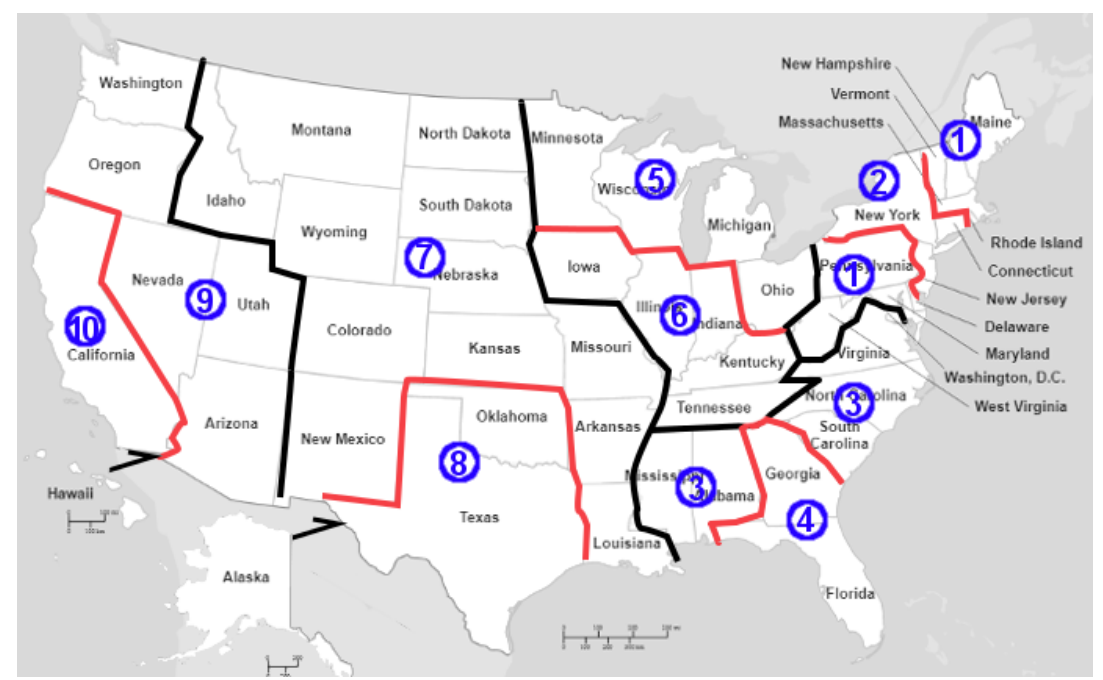

This ethnic conundrum will surely derail any future medical plan that doesn't strategically address it, as it has derailed previous efforts. Subdivided regions will have groups of about 32 million that are either less than 50\% white, or well over 60\%. The map illustrates the 10 subregions.

In the southeast, Florida, with 55\% whites, and Georgia, with 54\%, are in the midst of their "majority white” crisis. There may be no way to avoid their combination as a subdivision. Texas is peculiar, and a dangerous example, having less than $43 \%$ of its population white, yet still suffering revanchism. This is due to systematic suppression of non-white ethnic groups, particularly through restrictions that prevent them from registering to vote. ${ }^{72}$ Among self-reported registered voters in Texas, $64 \%$ are white, and only 19\% Hispanic. The last time whites made up 64\% of the actual Texas population was during the 1980s. Texas uses neo-Jim Crow strategies based on the size of the state and counties. Texas is very large, larger than any European country. At the same time it has 254 counties, most surprisingly small. California has 58, Alaska 19. Texas passed laws that make it a very expensive crime (with prison sentences) to register someone in the wrong county. Given the distances in Texas, that's impossible to avoid. This rule effectively banished registration efforts. Texas can't repress voters forever. The key is Latino economic development. White South Africans tried to use a much more draconian geographic approach to suppressing an ethnic group, black South Africans. Even this failed, once urban blacks gained assets and mobilized. 
Other states can’t reproduce the Texas model exactly, because none have the plethora of small counties where non-white majorities live. By 2040, the 10 subdivided regions will be able to reconvene into the 5 regions. Unless the nation as a whole veers towards an illiberal voting regime that excludes nonwhites, white-led opposition to rational health care delivery will no longer be consequential. At the same time, regions will have had time to develop expertise in health care administration.

During an initial phase there can be a roll out of an intermediate expansion of Medicare in all ten subregions. This could be either a "public option,” or expansion of Medicare to those between 50 and 65 years of age, or some other combination. Subregions are better than states as laboratories of democracy. They will all have similar populations, after all. They can follow different strategies, and outcomes compared. Although this model was tried with earlier programs like CHIP, it was always state by state. 15 prairie states have about as much population as California. Grouping the 15 together enables them to achieve their potential to perform as well as more densely populated regions. Subregions will have 32 to 34 million initially, which is a considerable challenge. Yet this Canadian size population should be sufficient for regions to attract and mobilize administrative expertise.

\section{(5) DIVIDE AND CONQUER}

The largest countries in the world, by geography, are Russia, Canada, the US, China, Brazil, Australia, and India. Six of them form pairs: the US and Russia, India and China, and Canada and Australia. They have similar demographic and geographic scales, and they're divided up into similar administrative or electoral units. China has slightly more people than India, but they both have enormous populations, each with more than four times the people of the next most populous, the US. China has almost 3 times as much land, but much is empty, unlike India's. India is composed of 36 state-like units, China 34.

The US, Russia, Canada, and Australia are the only big countries that span between two oceans. Canada's 37 million population is dwarfed by the US, and also by Russia's 148 million. Australia, however, has a similar small population, 25 million. It's also a continent-sized space with the Indian Ocean on one side, the Pacific on the other. Canada has 10 provinces, and Australia has eight states and territories. 
The US and Russia both have large land areas. Their populations are midway between the Canada/Australia level and the India/China one. Russia is three times the size of the US, but like China relative to India, the difference is relatively empty space. The US and Russia also have the most statelike units. Russia has 84 republics, krays, oblasts, okrugs, and municipalities. 81, if you don't count the cities. ${ }^{73}$ The 46 oblasts, most west of the Urals, are the size of many east of the Mississippi US states. The 22 republics are areas around the country's perimeter, like the various "stans" (Dagestan, Tatarstan.) The largest of these parallel the size of California and Alaska. The remaining okrugs are in the far corners, near Korea, China, and Finland.

Russia also considered consolidating its subdivisions, in 2000. Although Moscow historically rules Russia by central authority, after the Soviet Union fell in 1991 this changed. Power briefly devolved to its state-like units. By 2000 many were run like near autocracies, challenging Russian tradition. That's when Putin took office as President. His priority was for Moscow to retake central control. One of his first decrees was to divide the county into seven regional districts. ${ }^{74}$ The purpose wasn't to improve health care delivery or increase government responsiveness. Putin’s seven districts promoted a centralized legal system, replacing the many independent laws promulgated by smaller regions. The seven districts were also conduits for the security services to dominate states. The Putin administration was interested in control. Districts aren’t allowed autonomous leaders.

Russian health care suffers because its funding is decentralized, based on each localities capacities, while operations are controlled by the central government. The federal government can't monitor and manage actual health care delivery. Issues of quality and service are beyond it. Instead the Russian federal government pays for, and keeps an eye on, major capital expenses, especially buildings and equipment. So Russian hospitals may have nice facilities, and a fair distribution of modern equipment. But the staff and doctors can be poorly trained, unsupervised, unmotivated, corrupt or dangerous, and face few consequences. ${ }^{75}$ This is often what happens when a government controls local institutions, but

73 CIA, 2010, World Factbook, Washington, DC, Potomac Books

74 Hyde, M., (2001) "Putin's Federal Reforms and Their Implications for Presidential Power in Russia", Europe-Asia Studies, (53)5: 719-743

75 Rozenfeld, B.A., 1995 'The Crisis of Russian Health Care and Attempts at Reform', Chapter 5 in DaVanzo, J., and G.

Farnsworth, 'Russia's Demographic "Crisis"', Santa Monica, RAND 
lacks the capacity to manage them. Many US states are too limited to effectively monitor public classroom education. Instead they focus on school building construction. These expenditures are "one and done," not recurring. The result is that local control can lead to poor outcomes. In Russia it leads to a generally low level of health care service. In 2013, the lifespan of Russian men was 65, below Haiti's.

The highly centralized health care plans promoted by candidates for the 2020 Presidential contest take authority for hospital capital expenditure. It currently drives a lot of health care inflation. Hospitals that expand facilities and purchase equipment tend to earn more income. The only way to obtain financing for capital investment is from premiums and patient billing. This makes even non-profit hospitals raise prices, to generate enough profit. A government run and funded system can avoid this, in theory. What Russia illustrates is that it may not avoid it in practice, because buildings and equipment become the focus of interest for federal money. Under Medicare for All, administrations may lavish capital expenditures on health care infrastructure. Over a four year period, big new buildings can make a mark.

Russia doesn't decentralize well. If geography overwhelms those who invade Russia, it may overwhelm Russians as well. The US doesn't decentralize as well as it could, either, because states are so unequal in capacity, wealth, population, and diversity. Decentralization doesn't fit in a place where local people are isolated. Even urban dwellers in Russia can be isolated, because migration is difficult. ${ }^{76}$ Given the distances in the middle of the US, people can be quite isolated there as well.

A dependence on local, rather than federal health care funding, will aggravate inequality. It would produce very different services in different regions and states.

Americans migrate within their country much more easily than Russians in theirs. Decentralization is far more common. But there often remains a glaring disconnect between the federal and local levels. The invention of seven districts to cover all of Russia got off to a promising start, to bridge the gap between central authority and local health care. It fell victim to the harsh orientation of the Putin administration. But it's a theme worth considering.

76 Brunarska, Zuzanna, (2014) Regional out-migration patterns in Russia, European University Institute 
The countries of Scandinavia illustrate how new subdivisions can modified periodically. One of the primary reasons for changing state-units is to improve health care delivery. This isn’t a recent phenomena, but goes back hundreds of years, and continues still.

In Sweden there were, in centuries past, 25 historical regions. Today there are 21 modern county units. They follow historical boundaries closely, but not exactly. Sweden's public health model places most responsibility in the 21 counties, which govern hospitals. The Swedish federal government establishes guidelines, and reaches agreements with counties, as well as municipalities, the latter being responsible for elder care and the disabled. Counties and municipalities pay for most care, mostly out of their own tax revenue. But the Swedish government plans to merge the current 21 counties into six or nine larger regions, mainly to increase medical delivery economies of scale.

Denmark had 24 counties called Amt, formed in 1662 to carry out the king's decrees for hospitals, sick houses, and education. He wanted them properly distributed. That lasted until 1970, when they were consolidated into 14. In 2007 these were abolished and replaced by five larger regions, primarily to improve healthcare delivery. For over 300 years, healthcare has driven Danish geographical change.

Norwegian subdivisions date back to the 10th century. In 1919 these were grouped into 19 counties, then in 2017 they merged into 11 regions. Up till 2002 hospitals were operated by the 19 counties. Since then, the central government removed medical delivery from political units, and set up four regional health authorities. Each is an independent legal entity, structured like a corporation, and autonomous. Health care delivery improved. The four region health system is one reason Norway merged counties into regions.

Little research has examined whether American identity is linked to their state. The condition today is far different from the period prior to the Civil War. Then, when asked where they were from, even what country they belonged to, Americans often responded with their state's name. That changed after the war. Now people when in a foreign country, most answer they're from the USA. When asked where in the US, people often answer the name of the city closest to where they live, not the state. 
This parallels the way sports teams are named. Most professional teams have a city name, even if there is no competitor within the state, or within neighboring states, and even if their fan base is spread over multiple states. Of 133 professional sports teams in the US, only about 10 are named for states. Three states generate most of them: Colorado, Minnesota, and Arizona. So at first glance, identity is best served as an urban location, given most teams (121) have city names.

Yet evidence from college and professional athletic teams and leagues reveals that it isn't city or state identity that organizes fans. Popular teams have a regional identity. A typical survey finds the Dallas Cowboys capture fans in three or four states, as do the Green Bay Packers. The Atlanta Braves dominate fans in parts of ten states, the San Francisco Giants in two. The Denver Broncos have fans in a swathe that starts close to the Mexican border in Arizona, passes through the Rocky mountains, and ends near Canada.

Someone from western Nevada, when in a foreign country, will not say they're from San Francisco, even though they root for the San Francisco Giants. They may say “Reno” or “near Las Vegas”. If a foreigner isn't certain where those are, their next level of explanation is probably "in the American west” or "near the Pacific coast.” Regional identity is strong enough to be a common default. Someone from the Dakotas may find, when they visit Mongolia or Turkestan, that locals haven’t heard of those states. So they'll say something like "near Canada, in the western prairie.”

They could say it's part of the Louisiana Purchase. The many states now carved out of that territory make up the abundant sparsely populated states in the nation's center. Had that territory remained undivided, people in it might not feel so isolated, as they'd belong to a giant state with abundant people power. Instead, the region was explored on horseback, and settled that way too. Had airplanes and motor vehicles existed, the US would have fewer, larger states in the heartland.

Anecdotal evidence suggests that many Americans are anchored in a region of origin, not city or state. People from the New York metropolitan region, which includes parts of four states, may feel a stronger common identity than they do with people in upstate New York or inland Pennsylvania. Although large states like Texas have sufficient scale for residents to have a state-level identity, people along its Rio Grande valley may identify more strongly with others in Arizona or New Mexico. Some along the gulf 
coast share a strong regional identity as well. Isolated states like Vermont or West Virginia, or a religious one like Utah, may develop independent identities. Surely the human capacity to rally around one's tribe will encourage many people to claim fealty to their state. But it's easy to see that people in the Florida panhandle identify more with southern-tier Georgians and Alabamans, than with people in Miami. Many in the Rocky mountain area identify with the territory, not a particular state. Big sky country unites Montana, Wyoming, and maybe the Dakotas. In northern California people may identify more with Oregon than with Los Angeles, but the entire west coast shares a common identity. From west Texas up to Nebraska, many share a sense of common place, cowboy country.

Many of these regions overlap NCAA football conferences. There's a Big Sky conference with Montana, Idaho, and a smattering of more distant schools. The Big 10 has midwestern schools. The Mountain conference includes the schools from Colorado, Idaho, Utah, and a few from other states. The Patriot League groups smaller colleges in New England. And so on.

The U.S. Constitution was written when the country had less than four million people on 0.87 million square miles of land. Today it has 327 million on 3.8 million square miles. To wrangle different states into the union, the constitution gave states with smaller populations more voice. In 1789 the smallest state, Delaware, had 8.5\% the population of the largest, Virginia. Three states had less than 100,000, six others clustered around 200,000 and around 350,000, Pennsylvania 400,000, Virginia 700,000. A normal distribution.

Now the lay of land is different. Wyoming has $1.5 \%$ the population of California, six times smaller than Delaware in comparison to Virginia. The 18 smallest states have about the same population as Texas. So they have 36 Senators, and Texas two. As the US grew in scale, it's state disparities also grew. Their population distribution isn't normal any more, but skewed to the very small.

The stars on the American flag represent today's 50 states, the stripes the original 13. The flag's original meaning was different. The blue state area represented federal power, produced by the union of states. The European union flag contains white stars on blue to signify this as well. The first US flag, and all those since, had 13 stripes to represent state-level government. It probably would have made more sense to increase the number of stripes, and keep 13 stars. Stripes would have gotten very thin, while 
the stars would seem more and more remote. Visually, it would be better if today's 50 states were grouped in five or ten sections, each with five or ten stripes. That doesn't mean these sections are political units that mobilize national guards, operate universities, or collect taxes. They're an organizational tool. It's how we can squeeze all 50 in.

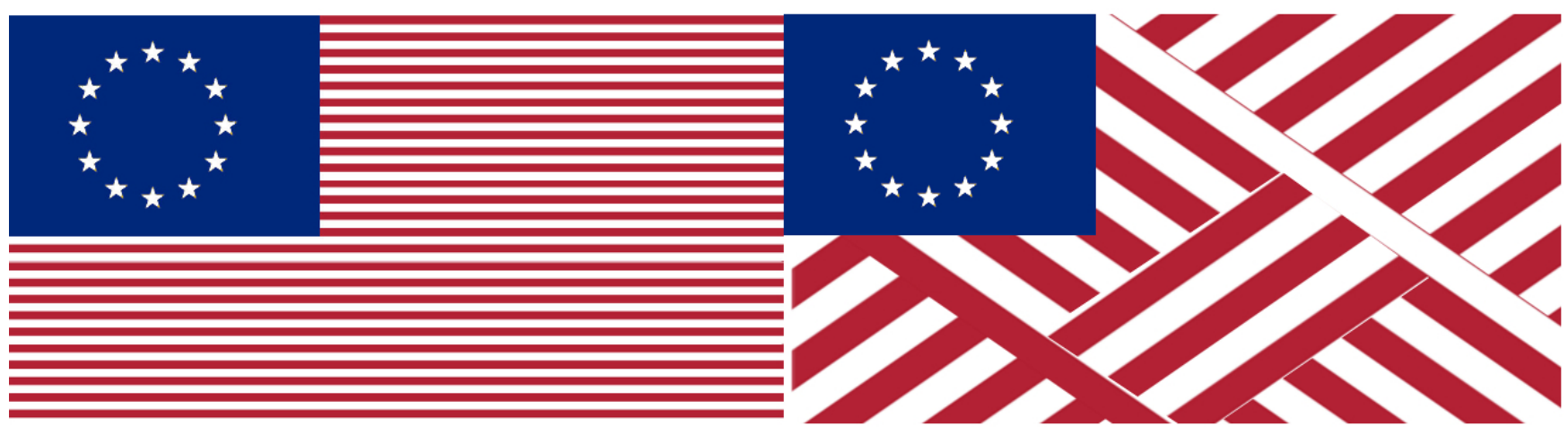

The US suffers because it lacks intermediate level sections, which could serve as administrative headquarters and organize national elections. The US hasn't adapted to the tremendous scale increase, in population and land, over the past 230 years. Things are run according to the dual levels of 1789 . Health care administration offers a chance to change that.

\section{SUMMARY}

It should be obvious that a roll-out of universal medical care, in a time of prejudice and polarization, will be awkward. This has happened before. Perhaps no one understood the process as well as Daniel Patrick Moynihan. He was instrumental in setting up both the Kennedy and Johnson administrations “Great Society” programs, from VISTA to Medicare. These had a profound impact on America, helping to reduce over-all poverty rates, and triggering a conservative, racially-couched backlash. Moynihan criticized policies for ignoring unintended impacts. He opposed the limit of Aid to Dependent Families (welfare) of only serving single-parent households. African-American families were systemically undermined since slavery (and still are, given the disproportionate imprisonment of black men.) The welfare rule was doubly damaging. First, because of the condition of many black families, it was perceived as a special benefit for African-Americans. Second, it would drive men out of poor families. 
Given black poverty rates, that would isolate and damage black families. If the nuclear family collapsed in one group more than others, Moynihan believed, it is disadvantaged against other groups. ${ }^{77}$

The left charged Moynihan with blaming the victim and promoting racial stereotypes; the right attacked him as a tax and spend liberal. When Nixon was elected he wanted to appear centrist, so he invited Moynihan to propose a welfare revision. Nixon surprisingly accepted it. It would have greatly expanded federal spending on low-income families, by paying income supplements to all poor families with children, regardless of parent status. It also involved job training, as Moynihan argued men needed jobs to stabilize their household role. A universal basic income would get rid of the perception of welfare as a privileged payment to dysfunctional families. It would become a legal right for stated benefits, like Social Security. The idea drew opposition from staunch conservatives and southern Democrats, but was derailed by liberal Democrats in the Senate. They preferred welfare's apparent focus on African-Americans, and disapproved of the jobs emphasis. Nixon soured on Moynihan, whose insights, in effect, failed to gain political support. ${ }^{78} 25$ years later Moynihan was New York's Senator, and watched right-wingers, now ascendant in the Republican party, gut welfare. He'd predicted it. ${ }^{79}$

This shaped Moynihan's response to President Clinton’s 1993 universal health care plan. He believed a sweeping overhaul of the health care system could be undermined by racial animosity, too. Minorities disproportionately lacked medical care, so the plan would inevitably focus on them. Moynihan also believed health care had to be a national program, not decentralized to unequal states. Offer Americans the same health care plan that every Senator got, regardless of where they were from. Each office holder and staff chose from a dozen or more plans, and many were multi-state or national in scope. The government paid about $75 \%$ of the cost of an average national premium, so enrollees paid more for expensive plans, less for frugal ones. Surveys monitored plan performance. Plans weren’t expensive, but maintained benefits and service.

The Clinton plan, on the other hand, was state-based. Employers paid into a state coffer $80 \%$ of their employees health care premiums, around what they were already paying to insurance companies. The state would use this money, along with supplementary funding of its own and the federal government,

77 Geary, D., Beyond Civil Rights, University of Pennsylvania, 2015 78 Nathan, R.P., (1996) A Retrospective on Richard Nixon, Presidential Studies Quarterly, 26:1: 155-164

79 Moynihan, D.P., and S.R. Weisman, Daniel Patrick Moynihan: A Portrait in Letters, Hachette, 2010 
to cover a lot of the insurance cost of every member of their state. Inevitably less populated states would have fewer plans, and less able governments to manage them.

The national and multi-state plans that Moynihan promoted were not of the type some conservatives want allowed, which are lower cost, fewer benefit plans. The federal employee plans were from national insurance companies such as Aetna or Blue Cross and Blue Shield Association, assembled through constituent regional or state-level companies. Less populated states had plenty of choice. Moynihan got minority leader Bob Dole to co-sponsor the bill. Like the ACA, it had mandates to have insurance, and subsidies to make it affordable. Moynihan knew people might not buy in, so it might never reach universal coverage. But he believed that when the President, and people in Congress, announced they were giving everyone access to their own medical care, it would overwhelm public distrust and avoid racial fear-mongering. ${ }^{80}$ Although not focused on the poor, its subsidies would be. Most Democrats and many Republicans supported it, and it probably could have passed. But it was killed by the Clinton administration, who wanted guaranteed universal care. ${ }^{81}$

In 2009 health care reform occurred. Though damaged by partisan opposition, a tremendous drop in the uninsured rate followed, based on commercial insurance and Medicaid. Now the 2020 election cycle has led to calls for universal health care coverage again.

The eventual roll-out of universal health care in the US requires time to develop required regional expertise. Evolution occurs generation by generation. Young people adapt to the failed attempts of their forebears. Moynihan provides such an example from a prior generation, which this generation can advance on. The importance of ethnicity is also clear. The ACA's naming as Obamacare singled its ethnic orientation to white Americans.

Rolling out a centralized national program will be massive, decades-long bureaucratic and enterprise effort, with as many levels of hierarchy as the US military. Rolling out a regional effort is more tractable, and can be accomplished with fewer risks and more care. Over 15 or 20 years expertise will develop. Different versions can be tried. Some sub-regions can offer a "public option,” and some can

80 Frank, J., (2017) On Health Care, We'll Have What Congress Is Having, New Yorker, Jan. 17, 2017

81 FIns, J.J., (2017) When Pat and Bob nearly saved health care reform, http://theconversation.com/ 
expand Medicare to people aged 50 to 65 . This will produce comparisons that could lead to better planning. This is a way to take advantage of US scale, which affords this kind of experimentation.

Eventually a centralized health care system will emerge.

\section{Brian Coyle}

brmcoyle@gmail.com

Box 176

Canyon, CA 94516 


\section{MEDIA HIGHLIGHTS*}

In Elizabeth Warren's and Bernie Sanders' “Medicare for All” plan, Medicare expands in 3 years from servicing 60 million to 180 million. They don't say how, but it's either done the Medicare Today Way, with insurance companies, or the Medicare Their Way, with government workers. Either way, you'll need at least $1 / 2$ a million new federal hires in 3 years, and at least 1 million new state employees.

It took the TSA almost a decade to hire 60,000. Sanders and Warren think that HHS can hire 10 times more in $1 / 3$ the time. Or soon-to-be defunct insurance companies will do the same.

We saw what happened when the ACA was rolled out to 12 million. Just a website. How do you make Americans love their health insurance? Make a Medicare mess.

Democrats: don’t forget that "dog whistle" politics isn’t about dogs. When red state Republicans talk about "states rights" it's not because they think their states are ready to run complex policy. It's code for wanting to discriminate. In fact, people in underpopulated states know their local governments don't have the capacity to run things the way coastal states do. When the ACA or Medicare for All proposals "devolve" operations to states, expect rejection in dog whistle code.

People aren't going to admit their communities' lack ability. Instead they couch objections in objectionable slogans. These contain a belief that dense, ethnically diverse coastal populations have the critical mass for federal attention and decent performance.

Size matters. Maybe Americans could remember it, when they try to understand reactions to energy policy or healthcare reform. Not just big companies, but the size of place. Americans have the biggest houses, cars, farms, hospital rooms, college dorms. Is it surprising the country binges on mortgages, lives in vehicles, eats too much, and spends lavishly on hospital and university buildings?

Big size helps when everyone pulls in the same direction. For anything else, it's a drag.

Canada has a tiny population compared to the US, but they're spread over just as wide an area. For decades, Canadians couldn't get their heads around healthcare reform. Liberals in cities kept proposing universal schemes, and conservatives is small towns kept objecting. Finally they agreed to let each region reform, within national guidelines. Then things really improved.

Instead of looking at where Canada is now, remember how it got there.

2* Please note these highlights are not an abstract or other part of the paper. 
The Medicare for All debate has only talked about cost. No one has explained how to run it. How many people get hired? If Medicare for All gets rid of insurance companies, it's really Veterans Care for All. Every doctor and technician is on government payroll. At least 5 million, probably 10 or 12 . At least twice the payroll of the Dept. of Defense, not a minor organization. No accounting system handles the DoD - it's too big, complicated, and siloed. The healthcare system is a hi-tech, highly trained, critical function sector, storing sensitive, regulated data in proprietary systems. No simpler.

As far as federal government oversight, handling customer service, managing money, those people number over a million no matter how the system operates. States employ four times as many. The countries that Medicare for All imitates - Canada, Britain, maybe France - all have a lot more people working for the government than in the US. Americans aren't keen on government work. We're like the Germans. They get to universal coverage using a system like the ACA. But everyone pays the same 7.5\% tax on income. Doesn't matter how old, young, sick, healthy, or how wealthy.

That's an idea to consider.

Sanders is quite willing to put giant health insurers out of business, but never talks about nationalizing them? The $\mathrm{N}$ word - nationalization - has a bad rap in America. It doesn't work for most companies. But insurance is different. It's all about numbers and statistics. CEOs and some investors would object, but purchasing them at fair market value is a way to bring hundreds of thousands of qualified workers on board quickly. It's fairer that putting them out of business.

Nationalization is also a natural way to expand a Public Option. As people switched from private insurers to the Option, companies could be nationalized, and their employees would be retained in the government program.

It's time to realize that American states were divided up for reasons that don't always make sense now. We don't travel on horseback, or have to balance free and slave states. The states in the middle seem huge, but they don't have enough people. They were carved out of bigger territories. The early states didn't want them too powerful. Other countries have this problem, and don't decentralize healthcare to states or their equivalent. Instead they combine them in regions.

When it comes to sports, Americans don't play games. We name the teams for cities, but fans are regional. The Broncos are for people beyond Colorado, the Braves beyond Georgia. Let's get regional. Divide the country into 10 sub-regions for healthcare administration, and fold those into five large regions when the program matures.

We're on a road about to make some hairpin turns, demographically. The US white population is falling below 60\%. In the antebellum south, in 1990s California, and in 1970s Brazil, the white population fell below $60 \%$ and all hell broke loose. Once they fall under $50 \%$, things can improve. 
The US west coast is already below 50\% (California's at 37\%.) It's "prairie" states and the southeast where white populations have dropped to 59\%. Nothing that appears to target non-whites with help will be an easy lift there, until the white percent falls below 50\%. Which will happen in 20 years.

We need to start health care reform in multiple regions simultaneously. Each has to serve the same number of people, and get the same money. They can try different ways, as long as the outcomes meet objectives. It will work best where whites are less than $50 \%$ or over $60 \%$ of the population.

The US can be divided into 10 regions of 30 to 35 million people each, where all the regions have either less than $50 \%$ whites, or more than $60 \%$. Except one, the southeast, where the division leaves Georgia and Florida together with 55\%. Can't be helped.

Let these 10 regions run health care reform for a decade, then see where we're at. In 15 years, every two regions can combine into one, now with 1/5 of the American population. The whole country will have less than $50 \%$ white population, and should be on a straighter path.

Finally, health reform is hard. We make it harder by ignoring social realities. The left believes it should be righteous, and demand the moon. They imagine they'll get $90 \%$, or even $2 / 3$ of what they want. Still enough to be great. That's not how politics works! When the left makes those demands, the right pushes the frightened masses buttons. Your taxes will pay for the healthcare of people who don't look like you, are lazy, illegal, or worse. You'll be denied care by people with Indian accents.

Respect the legacy of Patrick Moynihan, even if you can't do so publicly. He understood majorities need to be cajoled into supporting programs that serve minorities, even if the program serves everyone. Be creative. Moynihan wanted to give everyone the health plan that Senators got, along with subsidies, price controls, and the other stuff reformers wanted. He recognized this navigated past the fearmongering. But many didn't see it that way.

Send comments to:

Brian Coyle

Box 176

Canyon CA 94516

brmcoyle@gmail.com 